\title{
Archaeological Survey of the CPS Butler Lignite Prospect, Bastrop and Lee Counties, Texas, 1984
}

Anna J. Taylor

Follow this and additional works at: https://scholarworks.sfasu.edu/ita

Part of the American Material Culture Commons, Archaeological Anthropology Commons, Environmental Studies Commons, Other American Studies Commons, Other Arts and Humanities Commons, Other History of Art, Architecture, and Archaeology Commons, and the United States History Commons

Tell us how this article helped you.

This Article is brought to you for free and open access by the Center for Regional Heritage Research at SFA ScholarWorks. It has been accepted for inclusion in Index of Texas Archaeology: Open Access Gray Literature from the Lone Star State by an authorized editor of SFA ScholarWorks. For more information, please contact cdsscholarworks@sfasu.edu. 


\section{Archaeological Survey of the CPS Butler Lignite Prospect, Bastrop and Lee}

Counties, Texas, 1984

\section{Creative Commons License}

\section{(c) (1) \&}

This work is licensed under a Creative Commons Attribution-NonCommercial 4.0 International License 


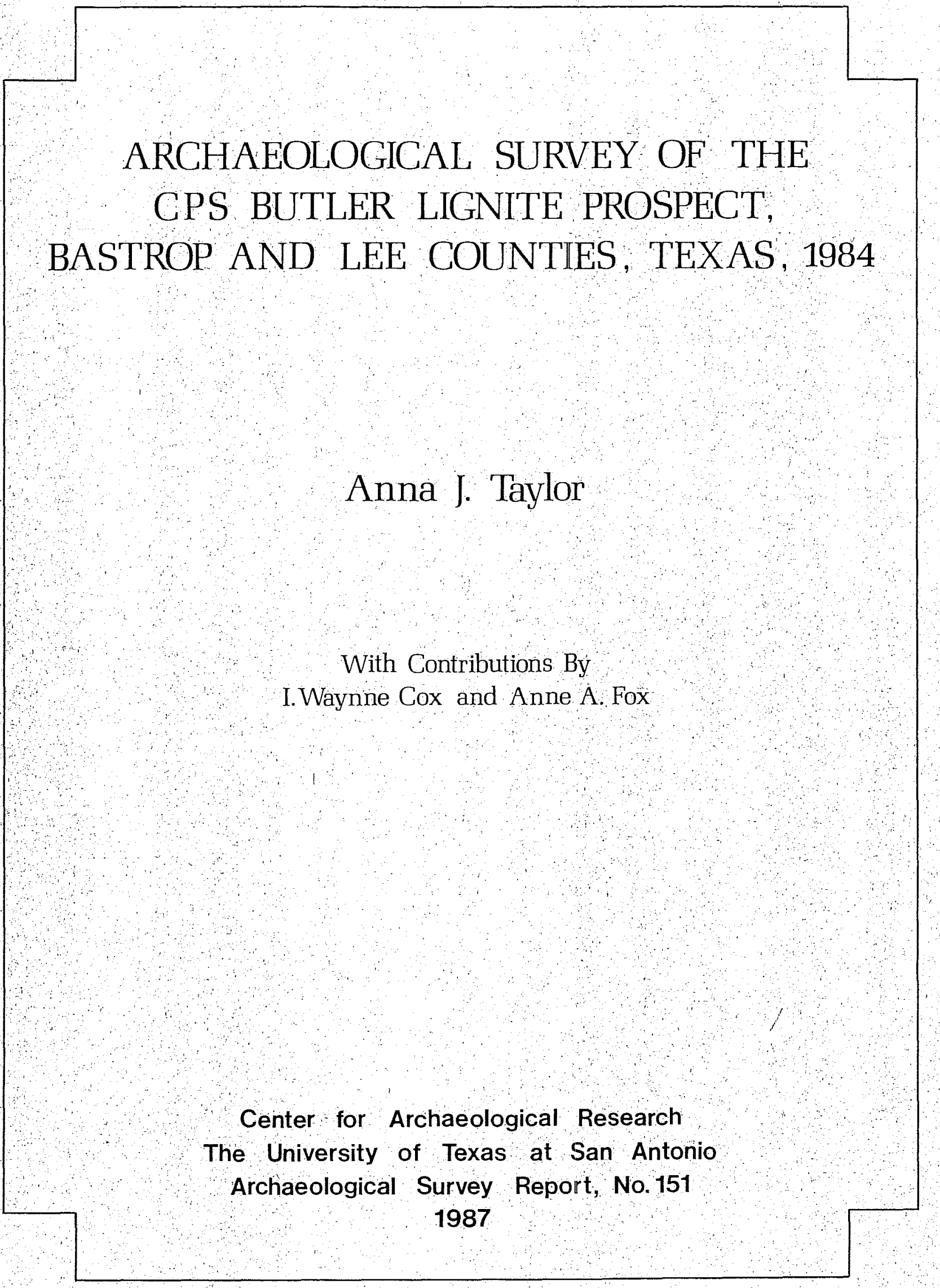



ARCHAEOLOGICAL SURVEY OF

THE CPS BUTLER LIGNITE PROSPECT,

BASTROP AND LEE COUNTIES, TEXAS, 1984

Anna J. Taylor

With Contributions By I. Waynne Cox and Anne A. Fox

Texas Antiquities Committee Permit No. 374

Thomas R. Hester, Principal Investigator

Center for Archaeological Research The University of Texas at San Antonio ${ }^{\circledR}$

Archaeological Survey Report, No. 151 
The following information is provided in accordance with General RuTes of Practice and Procedure, Chapter 41.11 (Investigation Reports) Texas Antiquities Committee:

1. Type of Investigation: Intensive Archaeological Survey of the CPS Butler Lignite Prospect;

2. Project Name: CPS-Butler, Phase IV;

3. Counties: Lee and Bastrop Counties, Texas;

4. Principal Investigator(s): Thomas R. Hester, Principal Investigator, and Jack D. Eaton, Co-Principal Investigator;

5. Name and Location of Sponsoring Agency: City Public Service (CPS) of San Antonio, Texas;

6. Texas Antiquities Committee Permit No. 374;

7. Published by the Center for Archaeological Research, The University of Texas at San Antonio, San Antonio, Texas 78285-0658, 1987.

A Tist of publications offered by the Center for Archaeological Research can be obtained by sending $\$ 1.00$ to the Center for Archaeological Research, The University of Texas at San Antonio, San Antonio, Texas 78285-0658. 


\section{ABSTRACT}

From July through September of 1984, personnel from the Center for Archaeological Research, The University of Texas at San Antonio conducted an intensive cultural resources survey of 984.96 hectares (2433.82 acres) of the CPS Butler lignite prospect in northern Bastrop County and southern Lee County, Texas. These investigations are part of a series of archaeological surveys sponsored by City Public Service of San Antonio, who plan a lignite mining project in the area. The purpose of the survey was to meet federal requirements of eligibility status of any archaeological site as to National Register of Historic Places qualification, so that proper measures can be taken prior to brush clearing in the area, and ultimately before any lignite mining activities occur.

Fourteen archaeological sites were identified during this project. The three prehistoric sites (41 BP 271, 41 BP 272, 41 LE 85) are all small 1ithic scatters. One of these sites, $41 \mathrm{LE} 85$, a7so has a historic component. None of the prehistoric sites are considered eligible for designation as a State Archeological Landmark or nomination to the National Register of Historic Places because of their low potential for yielding additional information.

Twelve historic sites were located during this investigation (41 BP 202, 41 $\mathrm{BP} 272,41 \mathrm{BP} 274,41 \mathrm{BP} 275,41 \mathrm{BP} 276,41 \mathrm{BP} 277,41 \mathrm{BP} 278,41 \mathrm{LE} 85,41$ LE 86, 41 LE 87, 41 LE 88, 41 LE 89), one (41 BP 202) of which was a previously recorded historic site. These sites are homesteads, outbuildings, and debris scatters. All of these sites are considered to be not eligible for designation as a State Archeological Landmark or nomination to the National Register as their information yield potentials appear to be $10 w$. 


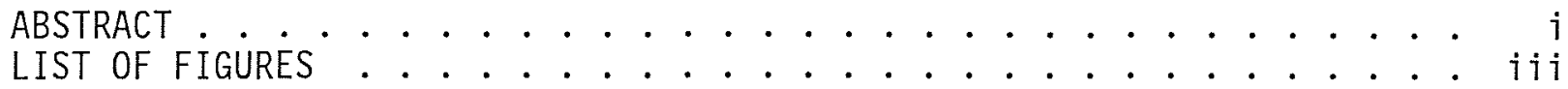

LIST OF TABLES .............................. . . . . . . .

ACKNOWLEDGMENTS ................... iv

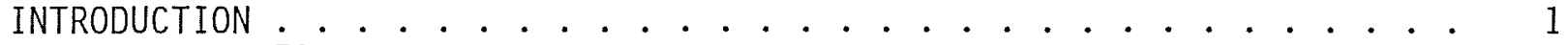

THE SURVEY AREA ................................ 1

Environmental Background ............... . 5

Archaeological Background . . . . . . . . . . . . . . . . . 6

Cultural History . . . . . . . . . . . . . . . . . 7

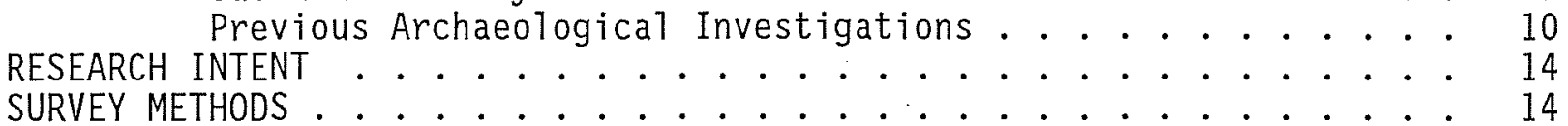

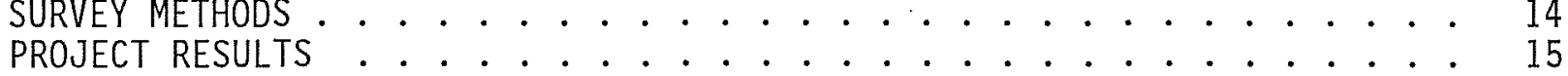

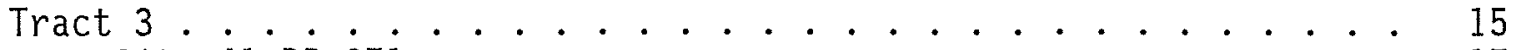

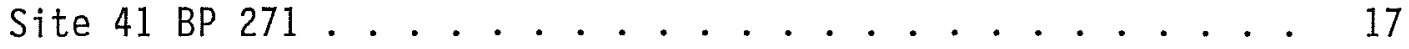

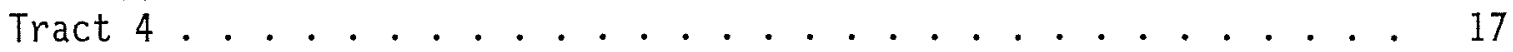

Site 41 BP 272 . . . . . . . . . . . . . . 17

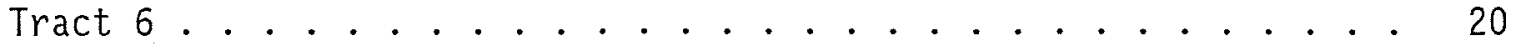

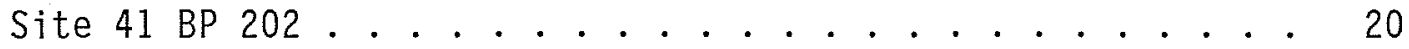

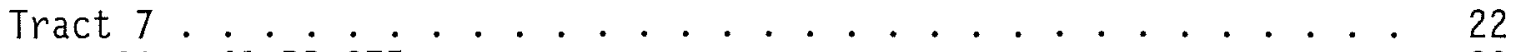

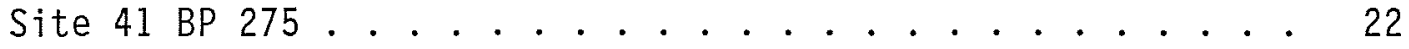

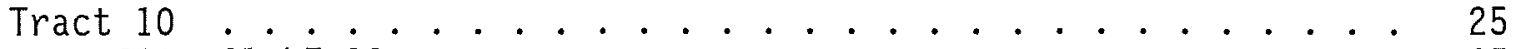

Site 41 LE 88 . . . . . . . . . . . . . . . 25

Tract 11 . . . . . . . . . . . . . . . . 27

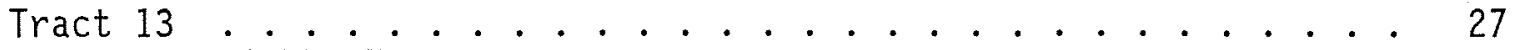

Site 41 BP $276 \ldots$. . . . . . . . . . . . . . 28

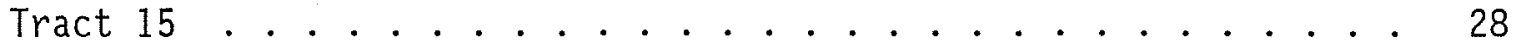

Site 41 BP 277 . . . . . . . . . . . . . . . 28

Tract $16 \ldots \ldots 30$

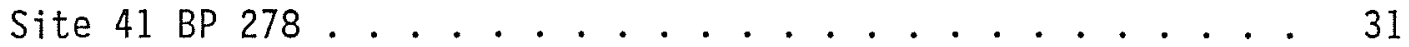

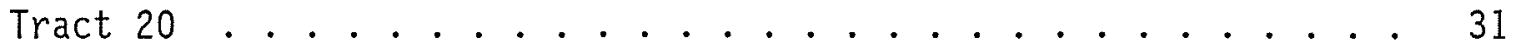

Site 41 LE 85 .................... 31

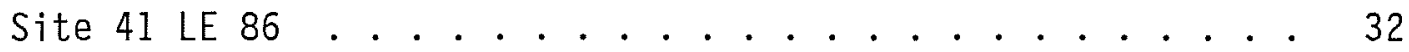

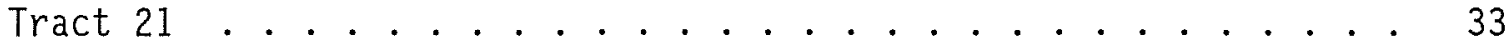

Tract 22 . . . . . . . . . . . . . . . . . 33

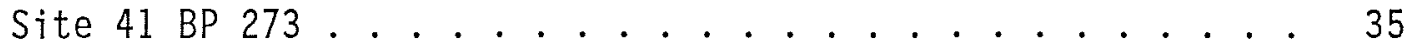

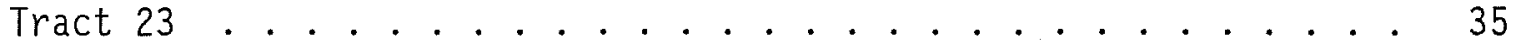

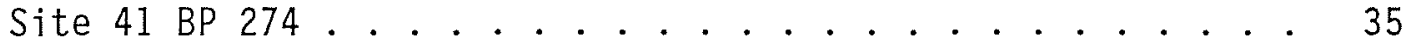

Tract 25 . . . . . . . . . . . . . . . . . 40

Tract 26 . . . . . . . . . . . . . . . . 40

Tract 27 . . . . . . . . . . . . . . . . 40

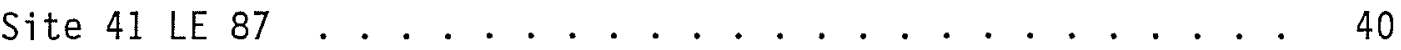

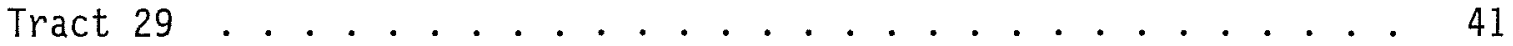

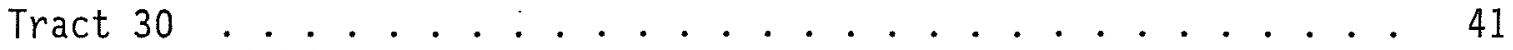

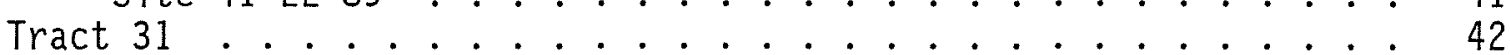

SUMMARY

Site 41 LE 89 ................ 41

REFERENCES CITED . . . . . . . . . . . . . . . . . 43

APPENDIX: PROPERTY OWNERSHIP RECORDS FOR THE SURVEY AREA

(I. Waynne Cox) 


\section{LIST OF FIGURES}

1. CPS But7er Northern Survey Area . . . . . . . . . . . . . . . . 2

2. CPS Butler Southern Survey Area . . . . . . . . . . . . . . . . . . 3

3. Views of Sites 41 BP 271 and 41 BP 272 .............. 18

4. Plan Map of Site 41 BP 272 . . . . . . . . . . . . . . . . . . 19

5. Plan Map of Site 41 BP 275 . . . . . . . . . . . . . . . . 23

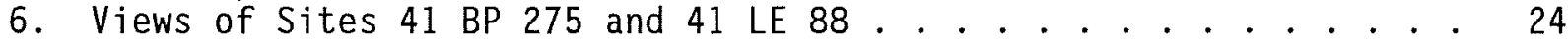

7. P1an Map of Site 41 LE 88 . . . . . . . . . . . . . . . . . 26

8. Plan Map of Site 41 BP 276 . . . . . . . . . . . . . . . . . 29

9. Views of a Deposit of Butler Bricks and Site 41 BP 273 . . . . . . 34

10. Plan Map of Site 41 BP 274 . . . . . . . . . . . . . 36

11. Views of Sites 41 BP 274 and 41 LE 87 . . . . . . . . . . . . . . 37

12. Artifacts from Site 41 BP 274 .............. . . 39

13. Original Land Grants Issued by the State of Texas Within the Survey Area . . . . . . . . . . . . . . . . . 51

\section{LIST OF TABLES}

1. Tracts in the Phase IV Survey Area and Previous Investigations . . 4

2. Prehistoric Sites in the Phases I-III Survey Areas . . . . . . . . 11

3. Historic Sites Within the Phases I-III Survey Areas . . . . . . . . 13

4. Sites in the Phase IV Survey Area by Component and Tract Location . 16

5. Historic Site Features in the Phase IV Survey Area . . . . . . . . 16

6. Artifacts from Surface Collections at Sites 41 BP 272

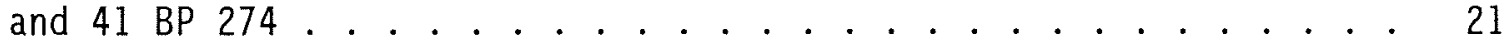




\section{ACKNOWLEDGMENTS}

Cindy Soulé of City Public Service (CPS), San Antonio, was especially helpful and provided much assistance during the survey and research aspects of the project. Some of the ranchers leasing CPS property included in the survey provided valuable information about the history and development of the study area. Other local inhabitants, such as Mrs. Erwin Roemer, Sr., Mr and Mrs. L. S. Clark, Mr. L. C. Hobbs, Mr. H. Turnipseed, Jr., and Bi11 McWi11iams of Elgin, also provided information and assistance during the survey.

The field survey was accomplished by Anna J. Taylor, research associate, and Elizabeth Craig and Kevin Jolly, archaeological assistants, all of whom are CAR-UTSA personne1. Volunteer Karen Jolly also assisted in the survey. Lynn Highley assisted in the laboratory preparation and analysis. David Hafernik drafted the maps, Margaret Greco drew the artifact illustrations, and Bruce Ellis did the artwork for the cover along with other drafting. Anne Fox identified the historic materials, and also provided advice and information concerning the historic sites. I. Waynne Cox researched the property ownership through deed records, and his information is included as an appendix to this report. The project was supervised by $\mathrm{Dr}$. Thomas R. Hester, principal investigator, and Jack D. Eaton, co-principal investigator. 


\section{INTRODUCTION}

City Public Service (CPS) of San Antonio contracted with the Center for Archaeological Research at The University of Texas at San Antonio (CAR-UTSA) to have an intensive cultural resources survey of recently acquired lignite prospect properties in Bastrop and Lee Counties, Texas, during July, August, and September 1984. The project area (Figs. 1 and 2) consists of 984.96 hectares (2433.82 acres) of land north-northeast of the small community and brickworks of Butler in northern Bastrop and western Lee Counties. The project was designated as phase IV, and is part of a continuing series of archaeological investigations in this area by CPS. Tracts 3, 4, 6, and 7, which were included in the phase IV survey, were previously investigated for CPS by personnel from the CAR-UTSA, during a reconnaissance-level survey (phase I) by Kelly and Roemer (1981). The current project was undertaken to enable CPS to begin brush clearing of the survey area, and also to meet federal requirements of the National Register of Historic Places so proper measures could be taken prior to lignite mining activities (Eaton 1983; Soulé 1983). The survey was carried out under Texas Antiquities Committee Permit No. 374 .

The phase IV survey was a $100 \%$ pedestrian survey of the project area done in regularly spaced transects. The project included surveying areas with relatively sparse vegetation and also thickly vegetated areas, on-site recording of sites, interviews with local informants, record research, analysis of collected materials, and preparation of a technical report describing the project.

The survey was done by Anna J. Taylor, Elizabeth Craig, and Kevin and Karen Jolly from July 30 to August 3, and from August 29 to September 12, 1984, a total of 14 field days. Waynne Cox conducted a deed record search of the surveyed tracts after the site report was completed. The results of his research are presented as an appendix to this report. The project was done under the supervision of Thomas R. Hester, the principal investigator, and Jack D. Eaton, the co-principal investigator.

\section{THE SURVEY AREA}

Tracts 3, 4, 6, 7, 9, 10, 11, 13-16, and 20-32, constituted the phase IV survey area. Thirteen of the surveyed tracts are in Bastrop County and comprise $61 \%$ of the project area with a total of 600.61 hectares (1484.103 acres). The remaining 11 tracts, which comprise $39 \%$ of the project area, with a total of 384 hectares (949.72 acres), are in Lee County. Kelly and Roemer (1981) previously did a reconnaissance survey of tracts 3, 4, 6, and 7 , and recorded one site (41 BP 202), which is discussed later in this report. The phase IV survey tracts, their respective area in hectares and acres, and a record of previous archaeological investigations and sites for each tract, are provided in Table 1. The results of the deed record research for the tracts are presented as an appendix to this report. 


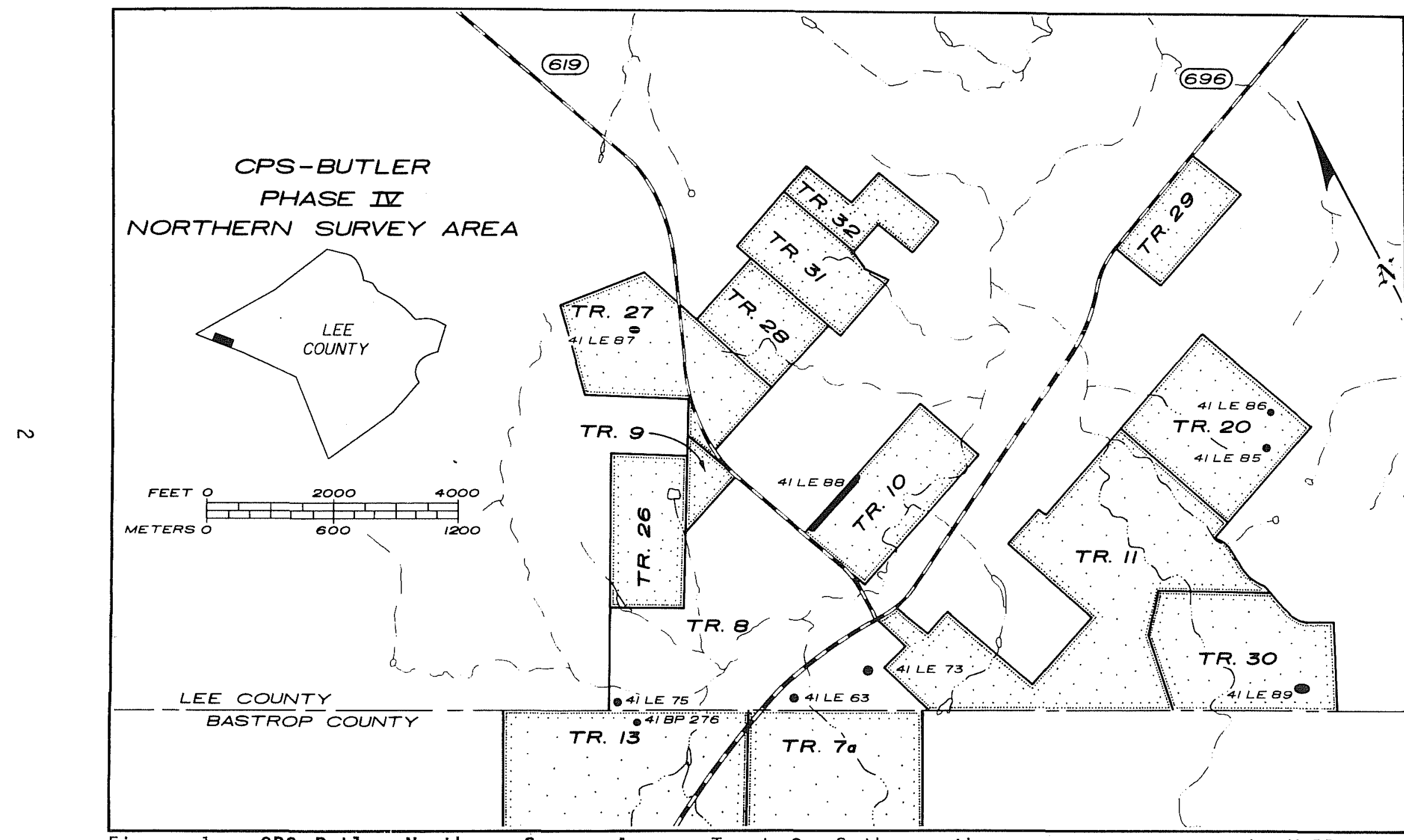

Figure 1. CPS Butler Northern Survey Area. Tract 8 of the northern survey area was in Kelly and Roemer's (1981) phase I survey area, and tract 8 was also in Brown's (1986) phases II and III survey area. The phase IV northern survey area includes tracts 9-11, 20, and 26-32, and these tracts are indicated by light stippling. 


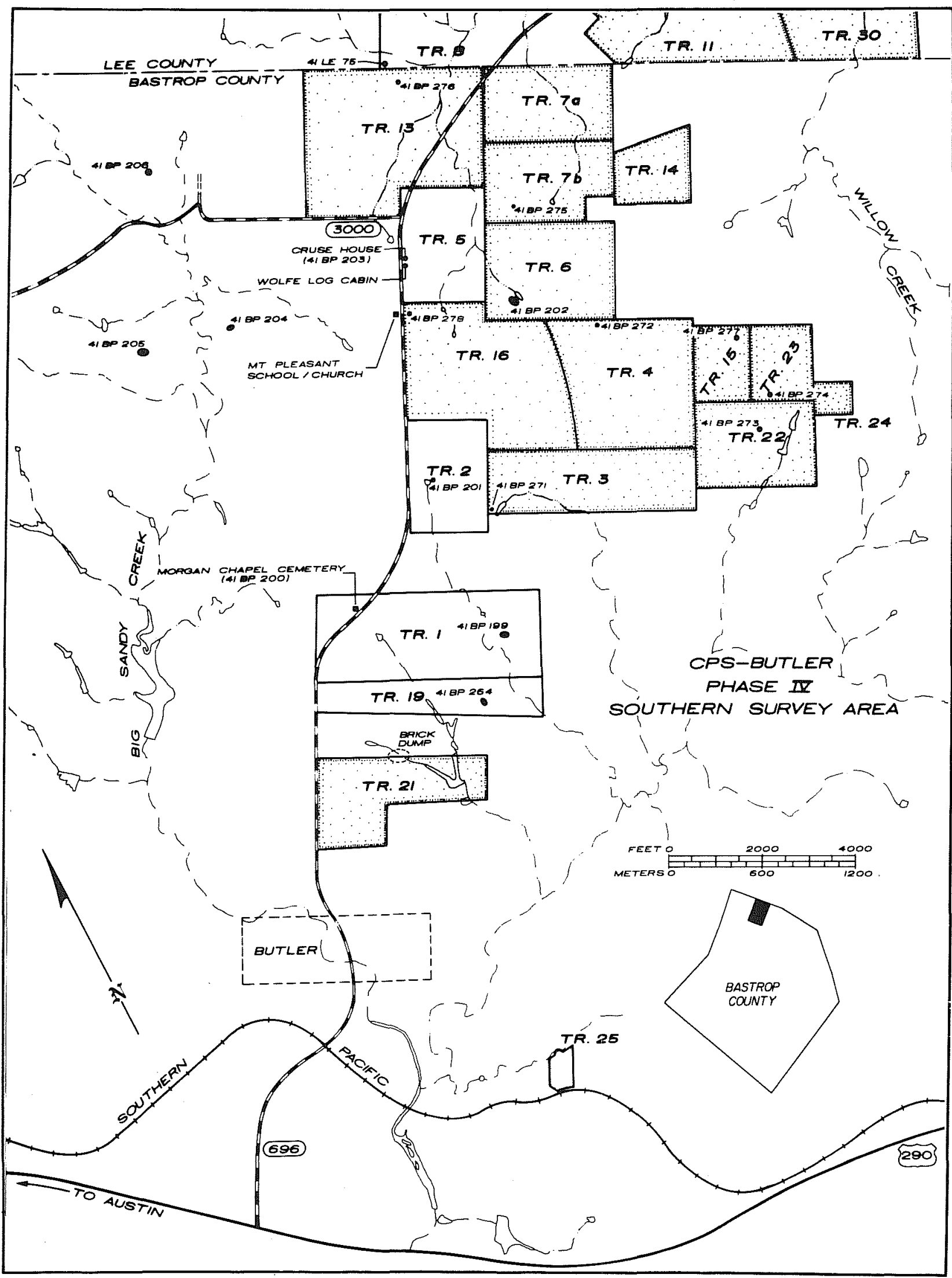

Figure 2. CPS Butler Southern Survey Area. Tracts 1-7 of the southern survey area were included in Kelly and Roemer's (1981) phase I survey area, and tracts 1, 2, 5, and 19 were in Brown's (1986) phases II and III survey area. The phase IV survey area includes tracts $3,4,6,7,13-16$, and 21-25, and these tracts are indicated by light stippling. 
TABLE 1. TRACTS IN THE PHASE IV SURVEY AREA AND PREVIOUS INVESTIGATIONS

Tract Hectares Acres Previous Investigations

\begin{tabular}{|c|c|c|c|}
\hline 3 & 55.49 & 137.12 & $\begin{array}{l}10 \% \text { reconnaissance survey coverage by Kelly and } \\
\text { Roemer (1981) }\end{array}$ \\
\hline 4 & 71.87 & 177.59 & reconnaissance survey by Kelly and Roemer (1981) \\
\hline 6 & 51.80 & 128.00 & $\begin{array}{l}10 \% \text { reconnaissance survey coverage by Kelly and } \\
\text { Roemer (1981), who recorded the Hackworth log } \\
\text { cabin (41 } \mathrm{BP} 202)\end{array}$ \\
\hline 7 & 81.09 & 200.37 & $\begin{array}{l}40 \% \text { reconnaissance survey coverage by Kelly and } \\
\text { Roemer (1981) }\end{array}$ \\
\hline 9 & 11.71 & 28.94 & none known \\
\hline 10 & 32.38 & 80.00 & none known \\
\hline 11 & 99.96 & 247.00 & none known \\
\hline 13 & 100.77 & 249.42 & none known \\
\hline 14 & 20.26 & 50.06 & none known \\
\hline 15 & 17.40 & 43.40 & none known \\
\hline 16 & 82.15 & 203.00 & none known \\
\hline 20 & 42.69 & 105.48 & none known \\
\hline 21 & 42.78 & 105.70 & none known \\
\hline 22 & 46.54 & 115.00 & none known \\
\hline 23 & 21.07 & 52.07 & none known \\
\hline 24 & 5.21 & 12.87 & none known \\
\hline 25 & 3.85 & 9.51 & none known \\
\hline 26 & 26.59 & 65.69 & none known \\
\hline 27 & 45.23 & 111.76 & none known \\
\hline 28 & 20.67 & 51.07 & none known \\
\hline 29 & 19.38 & 47.89 & none known \\
\hline 30 & 48.06 & 118.76 & none known \\
\hline 31 & 21.41 & 52.90 & none known \\
\hline 32 & 16.28 & 40.23 & none known \\
\hline TOTAL & 984.96 & 2433.82 & \\
\hline
\end{tabular}


With the exception of eroded areas, the project area (Figs. 1, 2) is characterized by deep, loose sandy soils, which include Demona loamy fine sand, and Axtel1, Crockett, Tabor, and Sayers fine sandy loam. These sandy soils developed on a compact, fairly impermeable sandy clay substrate which is part of the Calvert Bluff Formation. Contacts between the sandy and clay soils are often quite abrupt. The clay substrate varies from orange to blue gray in color, and may contain mudstone with sandstone, ironstone concretions, lignite, and sometimes glauconite; sandstone is occasionally exposed by erosion in the project area (Bureau of Economic Geology 1974; Brown 1986:2). Occasionally lag deposits of Pleistocene Uvalde gravel, which include chert cobbles, petrified wood, and quartzite, were found in the project area, particularly in the southern, more sandy tracts. The post oak region soils, which occur in the project area, are calcium-deficient and developed upon Eocene deposits, while the blackland prairie soils to the west are calcic and developed on Cretaceous marl. The San Antonio Prairie and String Prairie soils to the east developed on Eocene deposits (Bureau of Economic Geology 1974; Pool 1975:2-8; Brown 1986:4). Bastrop County is located just below the Balcones Escarpment and is within the Colorado River valley. A "petrified forest," or at least a concentration of petrified wood where stone tools and sherds were found, was reported at Loebau in southwestern Lee County (Webb 1952 Vol. I:120-121, Vol. I I:45).

In parts of the project area there are gullies which are quite large. Exposed subsoil areas are fairly common since the loose sandy soil is easily eroded by sheet wash. The quarrying of sand in parts of the survey area by the Butler Brick Company for brick tempering has added to the disturbance and erosion of the area (cf. Brown 1986).

Elevations within the project area range from approximately $146.3-175.3 \mathrm{~m}$ (480-575 feet) above msl (mean sea leve1), and the area is rolling to hilly. The average annual rainfa17 is $86 \mathrm{~cm}$ (34 inches). The average annual temperature is $66^{\circ} \mathrm{F}$ (Webb 1952 Vol. I:120, Vol. II:788).

The project area is within the post oak savannah vegetation region (Gould 1975), which is a remnant post oak woodland. The area has locally dense woodlands which at times are almost impenetrable, with oak, prickly ash, hickory, elm, cedar, yaupon, and hackberry trees, and also mustang grapevine, greenbriar, poison oak or ivy, frostweed, and a variety of other understory plants. However, to a great extent, the woodlands have been subject to modern land clearing practices. Willow, hackberry, sycamore, and pecan trees are found along the stream channels. Part of the survey area consists of unimproved or improved pastureland; the 1 and was cleared for farming within the last 120 years. In these cleared areas there are scattered cedar, oak, and mesquite trees, and dewberry vines. Cleared floodplain meadows have dense mixed grasses and forbs, whereas the cleared, more sloping upland areas have grasses and varying amounts of rattlebean and other understory plants. Brown $(1986: 4,5)$ describes various altered habitats within the study area of phases II and III, which were also encountered during the phase IV survey: recently abandoned fields; old fields currently used as pastures with mesquite and cedar trees; dense gallery woodlands which occur along streams; and undisturbed woodland areas which are predominantly confined to gallery 
areas and follow intermittent waterways, and correspond closely with the slightly more densely wooded areas which occur on valley slopes. The northwestern edge of the post oak region, where the blackland prairie begins, is approximately $4 \mathrm{~km}$ (2.2 miles) northwest of the project area. East of the project area are the San Antonio Prairie and the String Prairie.

There are numerous small, intermittent streams in the project area; some are dammed for stock ponds. These small streams are tributaries of Big Sandy Creek, which drains southward into the Colorado River, and Willow Creek, which drains northeastward into Middle Yegua Creek. The phase IV survey tracts predominantly drained by Sandy Creek are CPS tracts 3, 4, 15, and 2124, and those drained mainly by Willow Creek are CPS tracts 6, 7a, 7b, 9-11, $13,14,16,20$, and 26-32.

Although there are no springs within the project area, several springs are located in the general vicinity. Many springs in Bastrop and Lee Counties have failed in recent times, however, due to well pumping. In Bastrop and Lee Counties the springs issue mainly from Quaternary terrace sands and gravels along the Colorado River and other major tributaries, and also from Tertiary Eocene sands which include the Carrizo, Cook Mountain, Sparta, Reklaw, and Wilcox sands. The spring water is generally fresh and varies from soft to hard, with calcium and sodium bicarbonate, and may have a high content of iron (Brune 1981:59-61, 290-292).

Elgin Springs are in Bastrop County, approximately one mile west-northwest of Butler, Texas, south of the project area. These springs are located a short distance upstream from the Elgin, Texas, pumping station, and are now covered beneath sand (Brune 1981:59-61).

Darden Springs are in Lee County, east of the project area, approximately five miles west of Fedor, Texas, and near the ruins of the former community of Moab. These springs issue from a fault in the Queen City sands. Once the highly mineralized waters from Darden Springs were believed to have healing properties, and attracted people from afar to drink and bathe in the spring waters. Now, however, the spring waters are fresh. Knobbs Springs occur on the northern side of the sandstone Yegua Knobbs, and provided a plentiful supply of water for early settlers, and continued to be used until the late 1930s. The flow of Knobbs Springs has declined recently. North of the project area in Lee County, and approximately 2.5 miles south-southwest of Beaukiss, Texas, are Lawhon Springs, which were first named Yegua (Spanish for "small mare") Springs after a Tonkawa Indian camp located in this vicinity. They were then named Smith Springs after John Smith, who settled there around 1848. They may have later been named Lawhon Springs after David E. Lawhon, who moved to Bastrop County in 1858. The springs still flow, and are now diverted into two stock ponds (Brune 1981:290-292).

\section{ARCHAEOLOGICAL BACKGROUND}

The project area is located within the central Texas archaeological region defined by Suhm (1960:63) and by Prewitt (1981:71). Types of archaeological sites that typify central Texas are burned rock middens, concentrations of fractured burned rock mixed with artifacts and soil that mainly occur along 
the edges of the Edwards Plateau; deep terrace sites; and rock shelter sites. Both deep terrace sites and rock shelter sites have yielded much useful data for establishing and refining the prehistoric chronological sequence for central Texas (Prikryl and Ragsdale 1984:6).

\section{Cultural History}

Early archaeological investigators of central Texas who identified diagnostic prehistoric artifacts and proposed the first chronologies for the area include J. E. Pearce (1932), E. B. Sayles (1935), C. N. Ray (1934, 1938, 1945), and J. C. Kelley (1947a, 1947b). Suhm, Krieger, and Jelks (1954) established a chronological sequence that has served as the basis for subsequent chronologies proposed by Johnson, Suhm, and Tunne11 (1962), Sorrow, Shafer, and Ross (1967), Hester and Parker (1970), Weir (1976), and Prewitt (1981). Four developmental stages were proposed by Suhm, Krieger, and Jelks (1954:16-21): Paleo-American, Archaic, Neo-American, and Historic. Sollberger and Hester (1972:327) proposed a transitional Pre-Archaic period between the Paleo-American and Archaic stages (cf. Black and McGraw 1985); this modification, however, is not commonly used. The term Paleo-American has generally been replaced by the term Paleo-Indian, and the term NeoAmerican may be referred to as Late Prehistoric (Hester and Parker 1970), Post-Archaic (Prewitt 1974), or Neoarchaic (Prewitt 1981:68). All of these chronological sequences are dependent predominantly upon projectile points and other distinctive tool types, and upon the dating of these artifacts by radiocarbon dating.

In central Texas, the Paleo-Indian period is the earliest known cultural division, dating prior to ca. 8500 B.P. (Before Present, years calculated from A.D. 1950). Little is known about this early period in central Texas. Paleo-Indian components consist mainly of finds of isolated lanceolate projectile points. Certain studies have indicated that the subsistence strategy was based upon generalized hunting and gathering, instead of primarily the hunting of Pleistocene megafauna (Suhm, Krieger, and Jelks 1954; Bryant and Shafer 1977:19-20; Johnson 1977; Young 1984). Investigations at the Wilson-Leonard site (41 WM 235), which has a Paleo-Indian component, promise to yield more information about this period.

The Archaic period (8500-1250 B.P.) is generally divided into Early, Middle, and Late. Overall, the Archaic period is characterized by a hunting and gathering economy practiced by nomadic bands who occupied and utilized specific territories. During the Early Archaic period (8500-4600 B.P.), a scattered settlement pattern, with general hunting and gathering subsistence strategies, which may have emphasized gathering and numerous types of projectile points, was evidenced. At the end of the Early Archaic period, and throughout the Middle Archaic period (4600-2250 B.P.), burned rock middens were common, and the variety of projectile points decreases, which may indicate increased interaction between groups. The high number of projectile points and burned rock middens may indicate that hunting and gathering had somewhat equal emphasis. The Late Archaic period (22501250 B.P.) was characterized by an increase in the number of projectile point types, and the absence of burned rock middens in the eastern part of central Texas. During the latter part of the Late Archaic period, there was an 
increase in the kinds of specialized tools, and the proportion of projectile points to specialized tools decreased in comparison to previous phases, which may indicate that gathering activities predominated. A few isolated burials have been found which date to the latter part of the Late Archaic (Suhm, Krieger, and Jelks 1954; Weir 1976:125, 128-133; Prewitt 1976:93, 1981:73$74,81-82)$.

The Late Prehistoric period (ca. 1250-200 B.P.) is characterized by ceramics and arrow points, which first occur during this time. The Late Prehistoric period is usually divided into two phases: the Austin phase (ca. 1250650 B.P.) and the Toyah phase (ca. 650-200 B.P.). During the Austin phase, the subsistence strategy may have emphasized generalized gathering. It is during this phase that the first known cemeteries occur in central Texas. During the Toyah phase, pottery first occurred, and bison were heavily exploited. The tool assemblage changed to become more directed toward the procurement and processing of bison. The occasional appearance of corn cobs at sites may indicate indigenous horticulture or trade with horticultural groups (Suhm, Krieger, and Jelks 1954; Suhm 1957; Jelks 1962:84-99; Shafer 1971; Prewitt 1981:82-84).

During the early part of the Historic period (ca. 200 B.P.-present) in central Texas, a group of small, aboriginal bands joined together to form a confederacy which became known as the Tonkawa tribe. The confederacy was formed for protection against the encroachment of other aboriginal groups such as the Wichita, Apache, and Comanche tribes which were moving southward into central Texas in response to European expansion. It is possible that the Tonkawa were descendants of the Late Prehistoric period peoples who occupied central Texas. The Tonkawa were a nomadic hunting and gathering peoples who had what might be considered a plains culture and economy, and may have also practiced agriculture minimally. Many Tonkawa later moved to Spanish missions in east-central Texas for protection from other tribes, where they were grouped with more northern tribes. Other Tonkawa joined coastal Indian groups such as the Karankawa. Remnants of the Tonkawa occupied central Texas during the $1700 \mathrm{~s}$ and $1800 \mathrm{~s}$, until the United States government moved the tribe to the Brazos Indian Reservation in 1855, and to the Indian Territory north of Anadarko in what is now 0klahoma in 1857 (Webb 1952 Vol. II:788-789; Sjoberg 1953; Newcomb 1961:134-135; Jones 1969; Fox 1983:23-24). Comanche Indians were reported in the region at least until the 1830s. Few historic aboriginal occupation sites are reported or known for central Texas or the state in general. The Stansbury site (41 HI 9; Stephenson 1970) may be the only published report of a historic, non-mission related aboriginal occupation site. Some of the investigated Spanish colonial mission sites, such as the San Xavier Mission (Gilmore 1969), have produced a combination of both European and aboriginal-made materials (Newcomb 1961:134-135; Campbe11 1983:3-11; Fox 1983:23).

The municipality of Mina, named for Francisco Xavier Mina, was created by the government of Coahuila and Texas in 1834. The district became Mina County in 1836, under the Republic of Texas. The name was soon changed to Bastrop municipality, in honor of Felipe Enrique Neri, Baron de Bastrop, in 1837. Bastrop County was created in 1836, and was organized in 1837. It was one of the 23 original counties of the Republic of Texas, and included all or parts of 15 present-day counties (Webb 1952 Vol. I:120-121, Vol. II:204). 
Lee County was originally part of the Milam municipality. It was created by the Consultation of 1835, which set up a government for Texas as a state in the Mexican government. The Milam municipality, which was named for Benjamin R. Milam, had replaced the municipality of Viesca. Lee County was created in 1874, and was named for Robert E. Lee (Webb 1952 Vol. I:403, Vol. II:45, 192).

While traveling to study the fauna, flora, and geology of Texas, Ferdinand von Roemer followed the 01d Spanish Road, or the 01d San Antonio Road--now Highway 21--during Ju7y 1846, between Bastrop and Caldwel1. This location is approximately $20 \mathrm{~km}$ (12.4 miles) southeast of the project area. These travels occurred during the beginning of Anglo-European settlement of the region. Roemer's descriptions of the area show that the same natural areas currently recognized were also present at that early date. The early settlers, mainly small scale farmers, stockmen, and businessmen, chose at that time to claim open lands of the San Antonio Prairie rather than the post oak woodland and the Lost Pines area (Webb 1952 Vol. II:309-310, 498; Brown 1986).

The first reported settlement in the study region was known as Puesta del Colorado, and was built ca. 1823, in what is now Bastrop County. The settlement included a stockade located along a ford on the Colorado River; established to protect commerce along the 01d San Antonio Road. Puesta del Colorado was intended to serve as the base for a German colony which was established in 1823; the site, however, was abandoned due to persistent problems with the Indians. In 1828, an early Lee County settler, James Goacher, established a pioneer trail which became known as Goacher's Trace, and probably led from Rabbs Creek in southern Lee County to San Felipe and to Bastrop, connecting the upper and lower Austin colonies. Permanent settlement of Bastrop County was begun in 1829 by settlers from Stephen $F$. Austin's colony (Webb 1952 Vol. I:120-121, 697). Another early settlement was established in 1839, to the south of the project area at Camp Swift. By 1841, an Anglo-European settlement called Ft. Ridgeway was 1ocated on West Yegua Creek in north-central Bastrop County, which was attacked by Indians (Brown 1986, citing Jenkins 1958:68; Pierce 1969:122). The Yegua Knobbs area in northwestern Bastrop and Lee Counties was reportedly settled during the 1840 s by J. A. Tanner and others. In 1848, John L. Smith moved to Lawhon Springs in western Lee County (Brown 1986, citing Killen 1974:236-237).

The general project area is located within a corridor settled by Anglo immigrants from the upland South, many of whom brought black slaves with them. Wends, slavic peoples from Germany, settled east of the project area in Lee County during 1854, and soon built $10 \mathrm{~g}$ cabins and churches on the property which they had bought for $\$ .50$ per acre. German and Swedish immigrants settled west of the project area in Williamson County and northeastern Travis County (Webb 1952 Vol. II:45, 788-789, 879; Arbingast et al. $1973: 42)$.

The population of the region was sparse until the 1860 s, when settlement began to rapidly increase (Skelton and Freeman 1979:90, 92). By 1860, there was a post office at Blue Branch in western Lee County, and the Knobbs Spring Baptist Church was started in northwestern Lee County (Killen 1974:236). In Bastrop County, agriculture consisted chiefly of cotton production under the plantation system until the early 1880s. Much of the population farmed at or 
near the subsistence level until the 1870 s or 1880 s, when the first horsedrawn and steam-powered cotton gins was built in Bastrop County. Cotton then dominated the rural economy until market conditions changed, and the soil was depleted. The brick manufacturing industry in the area was begun in 1882 by Thomas $0^{\prime}$ Connor. The first bricks were made by hand, using wooden molds, and were then sun dried (Webb 1952 Vol. I:120-121, 697, Vol. II:788-789; Elgin Historical Commission 1972:37, 39; Brown 1986). (See appendix for further information regarding the history of specific ownership of the various tracts included in the study area.)

\section{Previous Archaeological Investigations}

The first archaeological site recorded for Bastrop County (41 BP 1) was investigated in 1953 by T. N. Campbell and E. B. Jelks. This site dated to the Late Prehistoric period, and included two human burials with Scallorn arrow points and ceramic sherds. The results of a student survey in Bastrop County during which 13 sites were found, were reported by Clark (1968:6). A large terrace site (41 BP 79), which included materials from the Early Archaic period, was reported by Duke (1977:15). Examination by Kelly and Roemer (1981:3) of what Duke described as a resharpened "Plainview Golondrina" point from $41 \mathrm{BP} 79$, dating to the Paleo-Indian period, resulted in its reclassification as a Paleo-Indian Golondrina point.

Skelton and Freeman (1979) of the Texas Archeological Survey conducted a large scale, intensive survey for the Lower Colorado River Authority of the Camp Swift area, south of McDade and Butler, Texas, and south of the CPS Butler project area. During the Camp Swift survey, 42 prehistoric sites and 43 historic sites were recorded, but very few time-diagnostic prehistoric artifacts were found. The Camp Swift and CPS Butler survey areas are both drained by Big Sandy Creek.

Kelly and Roemer (1981) of the CAR-UTSA, conducted a phase I reconnaissancelevel survey in Bastrop and Lee Counties, Texas, during July 1980 for CPS. The project area consisted of tracts 1-8 (Fig. 2), which were referred to as survey zones, with a total of 770 hectares (1900 acres). The current phase IV survey consisted of tracts 3, 4, 6, and 7 of Kelly and Roemer's (1981) project area (Figs. 1, 2). The survey included partial coverage of approximately $10 \%$ to $75 \%$ of the tracts, and was intended to assess the kinds of sites and potential archaeological problems that might be encountered by CPS during the planning stages for the anticipated lignite mining in this area.

Two prehistoric sites (41 BP 199 and 41 LE 63) were recorded by Kelly and Roemer (1981) during the phase I survey (Table 2). Two additional prehistoric sites (41 BP 205 and $41 \mathrm{BP} 206$ ) were recorded near the project area, but were out of the area of immediate concern to CPS. Another prehistoric site (41 BP 204) was found outside the project area, but was "within an additional area of CPS interest" (ibid.:iv) which was designated as Study Area B. Four historic Anglo-European sites (41 BP 200, 41 BP 201, $41 \mathrm{BP} 202$, and $41 \mathrm{BP} 203$ ) were recorded; three had houses and outhouses constructed within the last 100 years (Table 3 ). The remaining historic site was Morgan Chapel Cemetery (41 BP 200). No further investigations were considered necessary for the prehistoric and historic sites within the 
TABLE 2. PREHISTORIC SITES IN THE PHASES I-III SURVEY AREAS

Survey

Phase

Site

Description

I, II 41 BP 199 Archaic period. A thin lithic scatter with debitage, a dart point distal fragment of an unknown type, and a metate fragment.

II 41 BP 201 Undetermined period (associated with a historic component). One Tithic flake and core.

I 41 BP 204 Possibly Middle Archaic and Late Archaic periods, and Late Prehistoric period. Multifunctional campsite with lithic debitage, cores, ovate bifaces, a possible Carrizo point, a Pedernales point, Marcos points, a possible Castroville point, Fairland points, Ensor points, a possible Darl point, a Perdiz point, various unidentified dart points and bifaces, a Perdiz point, a sandy paste sherd, and burned sandstone.

I 41 BP 205 Late Archaic period. Multifunctional campsite with lithic debitage; Bulverde, Darl, Ensor, Palmillas, Marcos, Williams, and Morrill points; a cache of biface quarry blanks; and burned sandstone.

I 41 BP 206 Late Prehistoric period. Multifunctional campsite with lithic debitage; a core; Scallorn, Bonham, Bassett, and Perdiz points; and burned sandstone.

II,III 41 BP 264 Early Paleo-Indian and Middle Archaic periods. Multifunctional campite with lithic debitage, possible hammerstones, cores, a Plainview point, a possible Pedernales point, a clear Fork tool, a biface preform, manos, a metate, and fire-cracked chert and quartzite.

II 41 BP 265 Undetermined period. A light lithic scatter with debitage, a lithic core, and fire-cracked quartzite.

I, II 41 LE 63 Undetermined period. A thin lithic scatter of debitage. (Could not be relocated during the Phase II survey.)

II 41 LE 73 Late Prehistoric period (associated with a historic component). A light lithic scatter of debitage, cores, a biface fragment, a Scallorn point, a possible mano fragment, and fire-cracked rock.

II 41 LE 74 Undetermined period. A small work station of lithic scatter with debitage and a biface fragment. 
project area, with the exception of Morgan Chapel Cemetery (Taylor, Fox, and Cox 1986).

The results of the phase I survey, in addition to results of the archaeological survey at Camp Swift, approximately three miles south of the phase I survey area, indicated that prehistoric sites are unlikely to occur on upland areas, but rather are more likely to be concentrated within $200 \mathrm{~m}$ of stream channels, especially along Big Sandy Creek (Skelton and Freeman 1979; Hester 1981:iv).

In May and June 1983, Brown (1986) conducted phases II and III intensive survey in Bastrop and Lee Counties, with $100 \%$ coverage and testing for CPS. The project area included tracts 1, 2, 5, and 8, which were included in the Kelly and Roemer (1981) survey area, and also tract 19 (Fig. 2), for a total of 288 hectares (711 acres).

Seven prehistoric sites (41 BP 199, 41 BP 264, 41 BP 265, 41 LE 63, 41 LE 73, 41 LE 74, 41 LE 75) were found within the phases II and III survey area, two of which (41 BP 199 and 41 LE 63) were previously recorded by Kelly and Roemer (Table 2). A historic site (41 BP 201) recorded by Kelly and Roemer (1981) was found to have a prehistoric component. Brown was unable to relocate one of the prehistoric sites (41 LE 63) reported by Kelly and Roemer. Four historic Anglo-European sites (41 BP 201, 41 BP 203, 41 LE 73, 41 LE 75), in addition to Morgan Chapel Cemetery (41 BP 200), were also recorded (Table 3). Two of these sites (41 BP 201, 41 BP 203) have houses and outbuildings built within the last 100 years. One of the sites (41 BP 201) has a prehistoric component. The other two sites (41 LE 73, 41 LE 75) consist of scatters of historic debris with no structural remains. The Wolf family homestead (41 BP 201) possibly has one or two associated burials (Casey 1980). No further archaeological investigations were considered necessary within the project area, with the exception of Morgan Chape 1 Cemetery (41 BP 200), which was to be relocated at a later date (Taylor, Fox, and Cox 1986).

Examination of other recent archaeological surveys with $100 \%$ coverage in the Texas post oak belt and Brown's phases II and III survey and testing revealed that the site density in the phases II and III project area is roughly twice that of the other survey areas and is similar to the Camp Swift area despite the low number of sites found. Most of the other surveys within the region found what are called "lithic procurement" sites, which were lacking within the phases II and III survey area. Such sites are characterized by their location in upland areas near small tributaries, with sparse, shallow scatters of chipping debris and fire-cracked rock, and the sites often lack tools for which dates or functions are known (Brown 1986, citing Nightengale and Jackson 1983:21, Skelton and Freeman 1979:52-53, Kenmotsu 1982:53-55). The absence of this kind of site within the project area is suggested to be due to the lack of outcrops of lithic resources, with the exception of patchy occurrences of Uvalde gravel lag deposits, in the vicinity. The occurrence of numerous grinding tools at one prehistoric site (41 BP 264) was considered unusual for the area, and there was evidence of early occupation at that same site, which is also not common for the general locality. Excluding Morgan Chapel Cemetery (41 BP 200), which dates to 1891 or earlier, no historic sites dating prior to 1900 were located. There were very few structural 
TABLE 3. HISTORIC SITES WITHIN THE PHASES I-III SURVEY AREAS

Survey

Phase Site
Description
I-III 41 BP 200 Morgan Chapel Cemetery (1891-1937). A rural cemetery with 21 graves that were exhumed and relocated.
I,II 41 BP 201 Early 1900s (and an associated undetermined prehistoric component). House ruins and a split-log corncrib with historic debris. Possibly constructed and occupied by the Gordon Wolf family (ca. 1910-1930).

I 41 BP 202 A comparatively recent house built around an older $10 \mathrm{~g}$ cabin, and a split-log corncrib, which dates to at least ca. 1910, when it was occupied by the Hackworth family.

I,II 41 BP 203 A milled lumber frame house with hand-adzed foundation timbers and a divided split-log corncrib, which were constructed and possibly occupied by the William F. Cruse family (ca. 1890). A modern brick house (the Weisner home) with outbuildings is located to the southeast.

I , I I

The Wolf family homestead (ca. 1900 or earlier). A complex of abandoned 20th-century farm buildings in tract 1 ; older structures associated with the Wolf homestead were reportedly torn down. Mrs. Ada Casey (1980) of Elgin, who grew up in this area, reported one or two burials southwest of this homestead. One burial was of a woman named Craddock (spelling uncertain), dating to the early 1900s. The reported location was vague, however, and grave markers may be absent. Ken Brown (personal communication 1984) looked for but found no signs of any graves during his survey of this general area (Brown 1986).

II 41 LE 73 Possibly the William R. Mills homestead. The site consists of a light scatter of historic debris (1860-1870), but has no structural remains, suggesting that it is a historic dump rather than an occupational site.

II 41 LE 75 A small scatter of historic debris (1ate 1800s). 
remains or historic debris in the phases II and III study area, and practically no trace to early 1860s rural homesteads, even those which were previously documented.

During an extension of the phase III project, Taylor, Fox, and Cox (1986) assisted in the relocation of 21 graves from Morgan Chapel Cemetery (41 BP 200; Table 3). These excavations yielded information about local burial customs during the late 1800 s and early 1900s.

\section{RESEARCH INTENT}

The phase IV survey is part of a series of archaeological surveys, which number four to date, for the CPS Butler Tignite prospect which have been done for City Pubtic Service (CPS) of San Antonio by personnel of the Center for Archaeological Research at The University of Texas at San Antonio (cf., Kelly and Roemer 1981; Brown 1986). Though of larger scope, the present phase IV survey was intended to be similar to the phases II and III survey done previously by Brown (1986; Soulé 1983). The phase IV project was directed toward locating, recording, and assessing all prehistoric and historic sites determined to be 50 years or more in age that occur in the survey area ( $\mathrm{Ha} 11$ 1983); determining the National Register and State Archeological Landmark eligibility of each site, or making recommendations if additional investigations were needed to determine a site's eligibility; and generally adding to the present knowledge about regional cultural resources. The phase IV survey was intended to enable CPS to begin brush clearing of the project area, and also to meet federal requirements of the National Register of Historic Places which require that identified archaeological sites be assessed of their eligibility status so that proper measures can be taken prior to lignite mining activities (Eaton 1983; Soulé 1983). The survey was done in compliance with the National Historic Preservation Act of 1966 (as amended) and its implementing regulations, 36CFR800; the National Environmental Policy Act of 1969; Executive Order 11593; and was carried out under Texas Antiquities Committee Permit No. 374.

\section{SURVEY METHODS}

The intensive, $100 \%$ coverage field survey of the 984.96 hectare $(2433.82$ acre) phase IV project area (Figs. 1, 2) was conducted by walking linear transects spaced at approximately $20-\mathrm{m}$ intervals. Areas with sparse vegetation and areas exposed by erosion, road cuts, and animal burrows were visually inspected for archaeological materials and features. At some sites, erosion had removed much of the topsoil down to basal clay, and surface exposure of artifacts was therefore excellent. Also, the survey was conducted during the later part of a long, dry period which also added to surface exposure of materials. Surface collections, taken only from sites 41 BP 272 and 41 BP 274, were 1 imited to temporally diagnostic artifacts.

In areas with dense vegetation and poor ground surface visibility, shove tests were dug where the topography indicated possible locations for cultural remains; most of the shovel tests were dug at recorded sites, however. No further sites were discovered while digging the shovel tests in high 
probability areas. Usualiy one shovel test was dug at each site, though two were dug at some of the more extensive sites. The shovel tests were approximately $35 \mathrm{~cm}$ in diameter, and were dug to the basal clay, which generally occurred at a depth of less than $10 \mathrm{~cm}$ below the ground surface. The fill excavated from the shovel tests was not screened, but was broken apart for visual inspection for cultural materials. All artifacts recovered from the shovel tests were placed in labeled bags, and were returned to the CAR-UTSA laboratory for processing, analysis, and storage.

Black-and-white photographs and color slides were taken of each site with a 35-mm camera, and a photographic log was kept of the photographs and slides. The project director, Anna J. Taylor, kept a daily journal during the survey. A11 the project records are on file at the CAR-UTSA.

A11 the archaeological sites found during the phase IV survey were recorded on a standard State of Texas site survey form, and also on a CAR-UTSA site survey form. In the field, a sketch map was drawn of each archaeological site, with notations concerning site features, debitage and/or trash distribution, collected artifacts, shovel tests, landmarks, and topographic features; site locations were plotted on a 1-inch:1000-foot-scale blueline topographic map of the north Bastrop area provided by CPS. In the 1aboratory, site locations were also plotted on the current USGS Elgin East, McDade, Structure, and Beaukiss 7.5' topographic sheets.

\section{PROJECT RESULTS}

A total of 14 sites was observed in the survey area (Table 4). Three sites are prehistoric, and one of these (4I LE 85) also has a historic component. Twelve of the sites are historic, one of which (41 BP 202) was previously recorded by Kelly and Roemer (1981:18, 20, Fig. 7,a,b). Features observed or reported to be at the historic sites are presented in Table 5.

The 14 sites identified during the phase IV survey (also, cf. Tables 4 and 5 ) are described by the tracts in which they were found. Information concerning natural and cultural features is included for specific tracts, which are presented in numerical order. Each site is assessed in terms of its desirability for designation as a State Archeological Landmark and its National Register eligibility criteria. The historic materials observed and/or collected from sites were identified by Anne A. Fox. Architectural information and advice concerning the historic sites were also provided by Fox. Terms used to describe corncribs, which were at some of the historic sites, were taken from Jordan (1978). Waynne Cox investigated the sequence of land ownership for the study area; the results of his study are presented as an appendix to this report.

\section{TRACT 3}

During Kelly and Roemer's (1981) reconnaissance survey of tract 3 (Table 1) with $10 \%$ coverage of the area, no sites were located. One site, 41 BP 271, however, was located during the phase IV survey. Deposits of Uvalde gravel are exposed on the ground surface of this tract along with petrified wood, 
CPS BUTLER / Project Results

TABLE 4. SITES IN THE PHASE IV SURVEY AREA BY COMPONENT AND TRACT LOCATION

\begin{tabular}{llccc}
\hline Site Number & Prehistoric & Historic & Tract \\
\hline 41 BP 202 & - & $X$ & 6 \\
41 BP 271 & $X$ & - & 3 \\
41 BP 272 & - & $X$ & 4 \\
41 BP 273 & - & - & 22 \\
41 BP 274 & - & $X$ & 23 \\
41 BP 275 & - & $X$ & $7 \mathrm{~b}$ \\
41 BP 276 & - & $X$ & 13 \\
41 BP 277 & $X$ & $X$ & 15 \\
41 BP 278 & - & $X$ & 16 \\
41 LE 85 & - & $X$ & 20 \\
41 LE 86 & - & $X$ & 20 \\
41 LE 87 & - & $X$ & 27 \\
41 LE 88 & & & 10 \\
41 LE 89 & & & 30 \\
\hline
\end{tabular}

- = feature not observed

$X=$ feature observed

TABLE 5. HISTORIC SITE FEATURES IN THE PHASE IV SURVEY AREA

\begin{tabular}{|c|c|c|c|c|c|c|}
\hline Site Number & $\begin{array}{l}\text { Debris } \\
\text { Scatter }\end{array}$ & $\begin{array}{l}\text { Cistern } \\
\text { or Wel1 }\end{array}$ & $\begin{array}{l}\text { Dog-run } \\
\text { Corncrib }\end{array}$ & $\begin{array}{c}\text { House } \\
\text { Foundation }\end{array}$ & $\begin{array}{l}\text { Log } \\
\text { Cabin }\end{array}$ & $\begin{array}{l}\text { Wooden } \\
\text { Frame } \\
\text { House }\end{array}$ \\
\hline
\end{tabular}

$\begin{array}{lll}41 & \text { BP } & 202 \\ 41 & \text { BP } & 272 \\ 41 & \text { BP } & 274 \\ 41 & \text { BP } & 275 \\ 41 & \text { BP } & 276 \\ 41 & \text { BP } & 277 \\ 41 & \text { BP } & 278 \\ 41 & \text { LE } 85 \\ 41 & \text { LE } 86 \\ 41 & \text { LE } 87 \\ 41 & \text { LE } 88 \\ 41 & \text { LE } 89\end{array}$

\begin{tabular}{ll}
\hline$X$ & - \\
$X$ & 1 \\
$X$ & 2 \\
$X$ & 1 \\
\hline & 1 \\
$X$ & - \\
$X$ & 1 \\
$X$ & - \\
$X$ & 3 \\
$X$ & 1
\end{tabular}

- = feature not observed

$X=$ feature observed

$R=$ feature reported, but not observed 
quartzite, chert, and sandstone. Numerous fire ant mounds and rodent burrows were observed throughout the tract.

\section{Site 41 BP 271}

Site 41 BP 271 is an undated, presumably prehistoric, highland 1ithic scatter (Fig. 3,a). It is located in the southwestern part of tract 3 on the Elgin East, Texas, 7.5' USGS topographic map. The site elevation is 535 feet above msl (mean sea level). The site area gently slopes to the east, where there is a small, intermittent tributary. The ground surface has been subjected to sheet wash, resulting in a thin cover of topsoil. The site is in an improved pasture with a light cover of grass and forbs, with scattered mesquite, juniper, and oak trees, which offers fair ground surface visibility.

The site covers a $3-\mathrm{m} \times 6-\mathrm{m}$ area. No subsurface cultural materials were observed in a single shovel test which showed $3 \mathrm{~cm}$ or less of sandy loam soil overlying a sterile clay subsoil. Only one fragment of worked chert (a secondary flake), one chert core or core tool, and one possible quartzite mano fragment were observed. Gravels and cobbles of petrified wood, chert, and quartzite were present at the site and throughout the tract, but it is unknown if the utilized Tithic materials were obtained locally. No materials were collected from the site.

Because the cultural materials at 41 BP 271 are surficial, undated, and displaced, the site is not recommended for designation as a State Archeological Landmark, and is considered to be not eligible for nomination to the National Register of Historic Places.

\section{TRACT 4}

No sites were located during Kelly and Roemer's (1981) reconnaissance survey of tract 4 (Table 1). Modern trash dumps are in the central part of tract 4 near two stock tanks, and also in the south-central and southwestern parts of the tract. The northeastern part of the tract appears to have been terraced. A stand of pines is in the east-central part of the tract. The central and southwestern parts of the tract have been mined for sand. Some Uvalde gravel was exposed on the sand mining area. There are numerous rodent burrows and fire ant mounds in this tract. An isolated chert flake was observed in an area (southwestern part) with exposed basal clay that had been subject to sheet wash. No other cultural material could be located in the vicinity. Because of the disturbed nature of the surface deposits in this area, the flake was not recorded as a site. (See the appendix for further information.)

\section{Site 41 BP 272}

The ruins designated as site 41 BP 272 are possibly a homestead (Fig. 4). The site is located in the north-central part of tract 4 on the Elgin East, Texas, 7.5' USGS topographic map. The site elevation is 550 feet above msl. It is on a high terrace near a gentle western slope that leads to a small, 

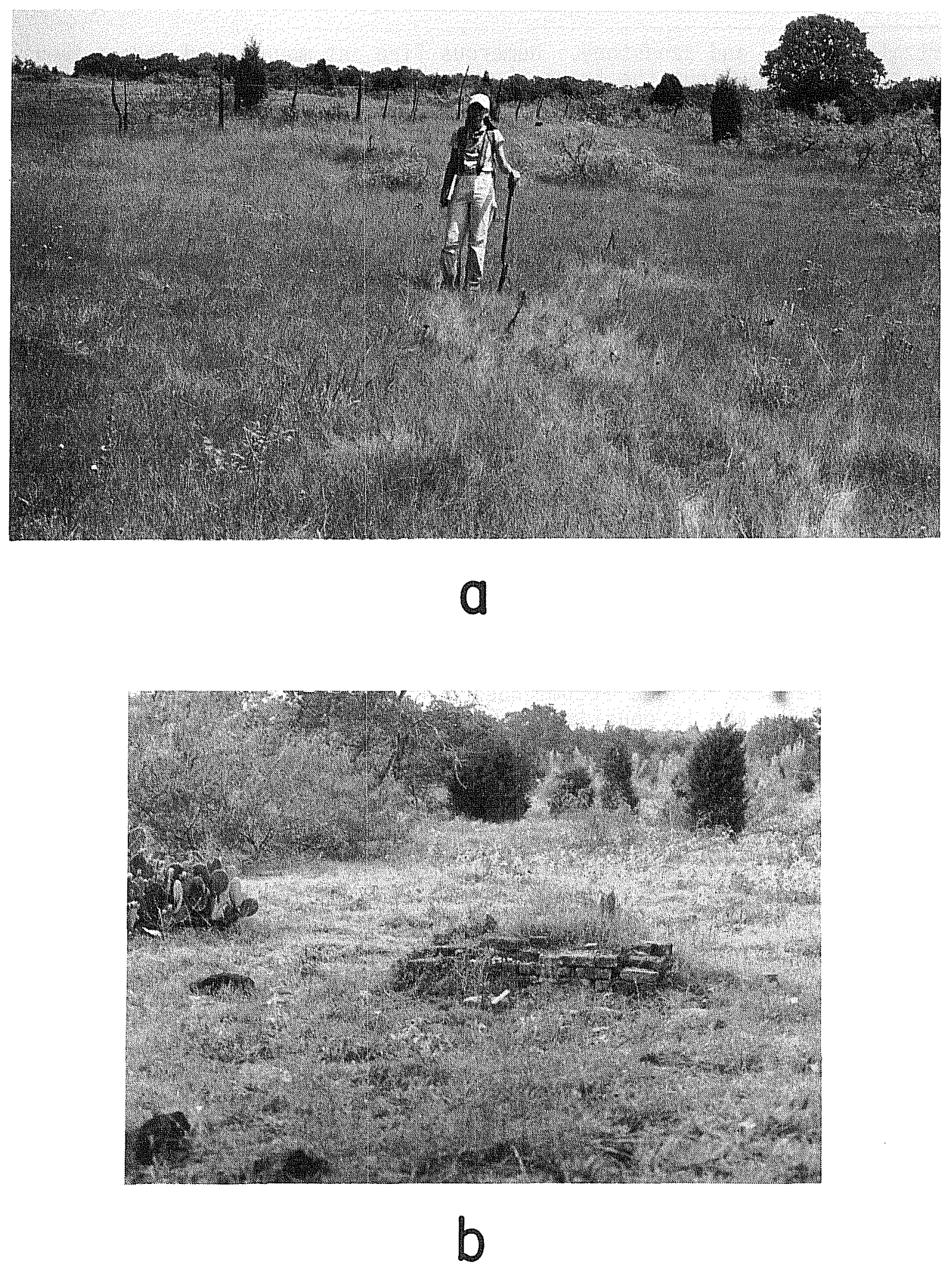

Figure 3. Views of sites 41 BP 271 and 41 BP 272. a, vegetation at a highland 1ithic scatter, site 41 BP 271 ; b, the brick hearth and loose sandstone foundation at site $41 \mathrm{BP} 272$, facing southeast. 


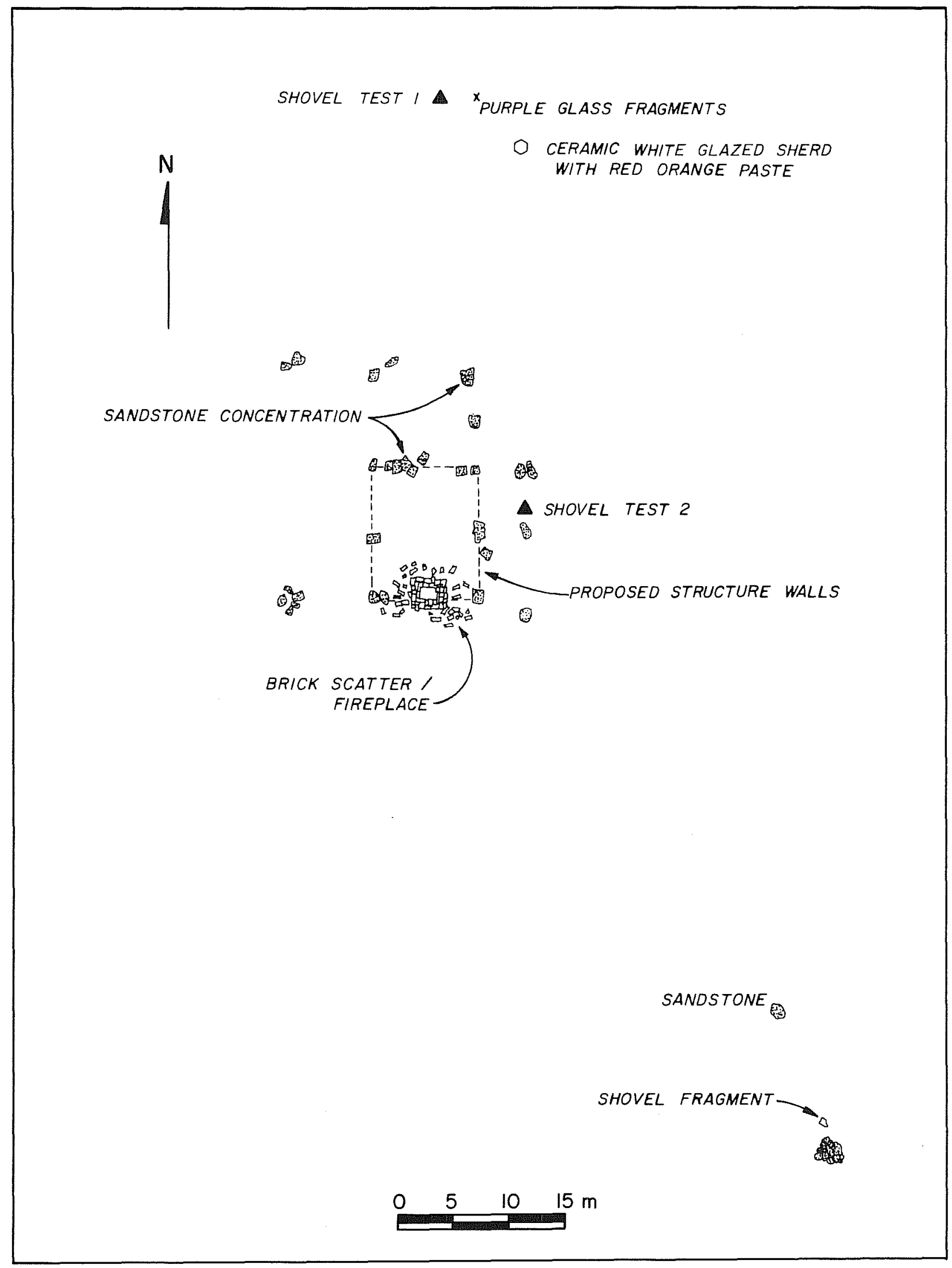

Figure 4. Plan Map of Site 41 BP 272. 
intermittent tributary. The site is in an improved pasture with a scattered growth of mesquite, hackberry, juniper, oak, and prickly pear, in addition to a thin to moderate growth of short grasses. The ground surface visibility is moderate. Animal burrows were present at the site.

The site covers a $24-\mathrm{m} \times 30-\mathrm{m}$ area. The ruins of a structure are represented by a loose, roughly shaped sandstone block foundation with a hearth made of brick and concrete mortar centered on the south side of the foundation (Fig. 3,b). Rotten timbers are present inside the foundation, and scattered b7ocks of sandstone and small concentrations of sandstone are located within $45 \mathrm{~m}$ from it. Two shovel tests dug at the site showed from $10 \mathrm{~cm}$ to $19 \mathrm{~cm}$ of tan sandy loam overlying a compact, sterile, red clay subsoil. No cultural materials were found in either shovel test. The cultural materials observed on the surface were two iron plow blades, a shovel blade fragment, and three fragments of window pane glass; none were collected. Collected were two fragments of purple glass and one white slipped Bristol glaze stoneware sherd with a red orange paste (Tab7e 6). Materials observed and collected at the site generally date to the late 1800s and the early 1900s.

The research potential of the scanty surface and subsurface deposits and the structural remains at site 41 BP 272 are judged to be 10 w. For this reason, the site is not recommended for designation as a State Archeological Landmark, and is judged to be not eligible for nomination to the National Register of Historic Places.

\section{TRACT 6}

Much of tract 6 was overgrown with a dense secondary growth of trees and vines. The tract appears to be subject to flooding, judging from the amount of debris and silt in the area that appeared to be water deposited.

A historic site, 41 BP 202, known as the Allison site or homestead, is located within tract 6 . The site was recorded and assessed by Kelly and Roemer (1981:18, 20, Fig. 7,a,b) during their reconnaissance survey (Tables 1, 3). During the phase IV survey, the site was not further investigated other than to verify the site location. The archaeologists felt that additional investigation was not called for during the phase IV survey level of investigation since the site had already been recorded, assessed, and reported for CPS.

\section{Site 41 BP 202}

The Allison homestead is in the southwestern part of tract 6 in a cleared pasture on the gentle northeastern slope of a highland terrace near a sma11, intermittent tributary and a stock dam. The site is on the Elgin East, Texas, 7.5' USGS topographic map at an elevation of 538 feet above ms 1 .

The site covers an area estimated to be a minimum of $2500 \mathrm{~m}^{2}$. Included within this area is a $\log$ cabin onto which was constructed a modern house that largely absorbed the original log cabin. The $10 \mathrm{~g}$ house is estimated to have been built ca. 1880-1900. The Hackworth family lived in the house in 
CPS BUTLER / Project Results

TABLE 6. ARTIFACTS FROM SURFACE COLLECTIONS AT SITES 41 BP 272 AND 41 BP 274

\begin{tabular}{|c|c|c|}
\hline Site Number & $\begin{array}{l}\text { Total } \\
\text { Collected }\end{array}$ & Collected Artifacts \\
\hline 41 BP 272 & $\begin{array}{l}1 \\
2\end{array}$ & $\begin{array}{l}\text { Bristol glaze stoneware body sherd } \\
\text { Purple glass goblet stem and unidentified fragment }\end{array}$ \\
\hline $\begin{array}{l}41 \text { BP } 274 \\
\text { southwest of } \\
\text { Cabin A }\end{array}$ & $\begin{array}{l}1 \\
1 \\
2\end{array}$ & $\begin{array}{l}\text { Clear glass fragments, } 3 \text { from a bottle with } \\
\text { embossed lettering, and } 1 \text { from a recent bottle or } \\
\text { window glass } \\
\text { Pale purple pressed glass fragment } \\
\text { Square cut nai } 1,3-7 / 8 \text { inches long } \\
\text { Round wire nails, } 1-5 / 8 \text { inches and } 2-3 / 4 \text { inches } \\
\text { long }\end{array}$ \\
\hline
\end{tabular}

$\begin{array}{lll}41 \text { BP } 274 & 2 & \begin{array}{l}\text { Square cut nai1s, } 3-1 / 4 \text { inches long } \\ \text { Round wire nai1, } 5-3 / 4 \text { inches long }\end{array} \\ \text { Cabin B } & 1 & \end{array}$

\begin{tabular}{|c|c|c|}
\hline $\begin{array}{l}41 \text { BP } 274 \\
\text { between } \\
\text { Cabins A } \\
\text { and B }\end{array}$ & $\begin{array}{l}1 \\
3 \\
2 \\
7\end{array}$ & $\begin{array}{l}\text { Undecorated whiteware sherd } \\
\text { Molded whiteware sherds with aqua stripe } \\
\text { Molded whiteware sherds with aqua paint over the } \\
\text { glaze } \\
\text { Plain white porcelain sherd } \\
\text { Plain yellow ware sherds. } \\
\text { Stoneware sherds with a Bristol glaze } \\
\text { Milk glass jar lid liner fragments, } 5 \text { with no } \\
\text { marks, and } 2 \text { with marks: "NED CAP" } \\
\text { Clear bottle glass fragments, } 1 \text { from a screw top } \\
\text { jar } \\
\text { Clear plate glass fragment, } 1 / 4 \text {-inch thick }\end{array}$ \\
\hline $\begin{array}{l}41 \text { BP } 274 \\
\text { southwest of } \\
\text { Cabin B }\end{array}$ & $\begin{array}{l}3 \\
1 \\
6 \\
1 \\
1 \\
5 \\
2\end{array}$ & $\begin{array}{l}\text { Clear pressed glass fragments } \\
\text { Purple bottle base fragment } \\
\text { Pale purple pressed glass fragments } \\
\text { Pale green canning jar lid fragment } \\
\text { Gold glass fragment } \\
\text { Brown bleach bottle fragments } \\
\text { Brown bottle with marks on panel, "HE" and } \\
\text { "S" }\end{array}$ \\
\hline
\end{tabular}


1910, according to a local informant (Hoerman 1980). A split-log double-crib barn, or dog-run corncrib, is north of the house and was sti11 in use during the 1980 survey. Local informants noted that corncribs were still generally in use until the 1930s in this area. The site appeared to be vacant during the later phase IV survey. (See the appendix for additional information.)

Kelly and Roemer (1981:20) concluded that the site has "doubtful historic value." A7though the original $\log$ house might be 50 years or $01 \mathrm{der}$, continual usage of and additions to the structure have led to the alteration of earlier features. These modifications detract from its potential eligibility to the National Register. Also, corncribs are not uncommon in the area. For these reasons, the site is not recommended for designation as a State Archeological Landmark, and is judged to be not eligible for nomination to the National Register of Historic Places.

\section{TRACT 7}

Tract 7 was previously investigated during Kelly and Roemer's (1981) reconnaissance survey (Table 1), but no sites were located at that time. For the phase IV survey, tract 7 was subdivided into a northern and a southern tract, designated as $7 \mathrm{a}$ and $7 \mathrm{~b}$, respectively. Much of tract $7 \mathrm{a}$ is covered with dense vegetation, with extensive deep gullies in the eastern part and a formerly plowed, sandy field in the western part. Portions of tract $7 \mathrm{~b}$ not along the tributaries are improved pasture.

\section{Site 41 BP 275}

Site 41 BP 275 is a historic homestead (Fig. 5) located in the southwestern part of tract $7 b$ on the Elgin East, Texas, 7.5' USGS topographic map. The site elevation is 530 feet above ms 1 . The site is in an open pasture with a sparse growth of short grasses, scattered mesquite, and irises and hackberry trees growing around the house. Sheet erosion has occurred across much of the site due to the scanty ground cover, and much of the site is eroded down to the basal clay. The ground surface visibility was, therefore, excellent. The site area is on top of a terrace which slopes to the northeast and west, toward two small, intermittent tributaries.

The site covers an area rough 7 y $22 \mathrm{~m} \times 30 \mathrm{~m}$ and includes a standing L-shaped, wooden frame house (Fig. 6,a) that is in fair condition and faces south toward an unpaved county road. The house measures $9.5 \mathrm{~m} \times 16.5 \mathrm{~m}$ and has a corrugated tin roof with a steep pitch and shallow eaves; exterior, horizontal machined lap siding; and porches with turned porch posts along the north, east, and south sides of the house. The house foundation is of post and beam construction with handmade and machine-made brick posts. There are five rooms and a hallway in the house; four of the rooms are joined north to south, while the remaining room forms a southeast wing. The interior of the house has machined pine wainscoting and two brick fireplaces with decorated wooden fronts. The house interior has exposed electric wiring which may have been added after the house was constructed. The northernmost room appears to be a later addition judging by the abutment visible on the exterior of the house, but the same materials were used to construct this addition. The 


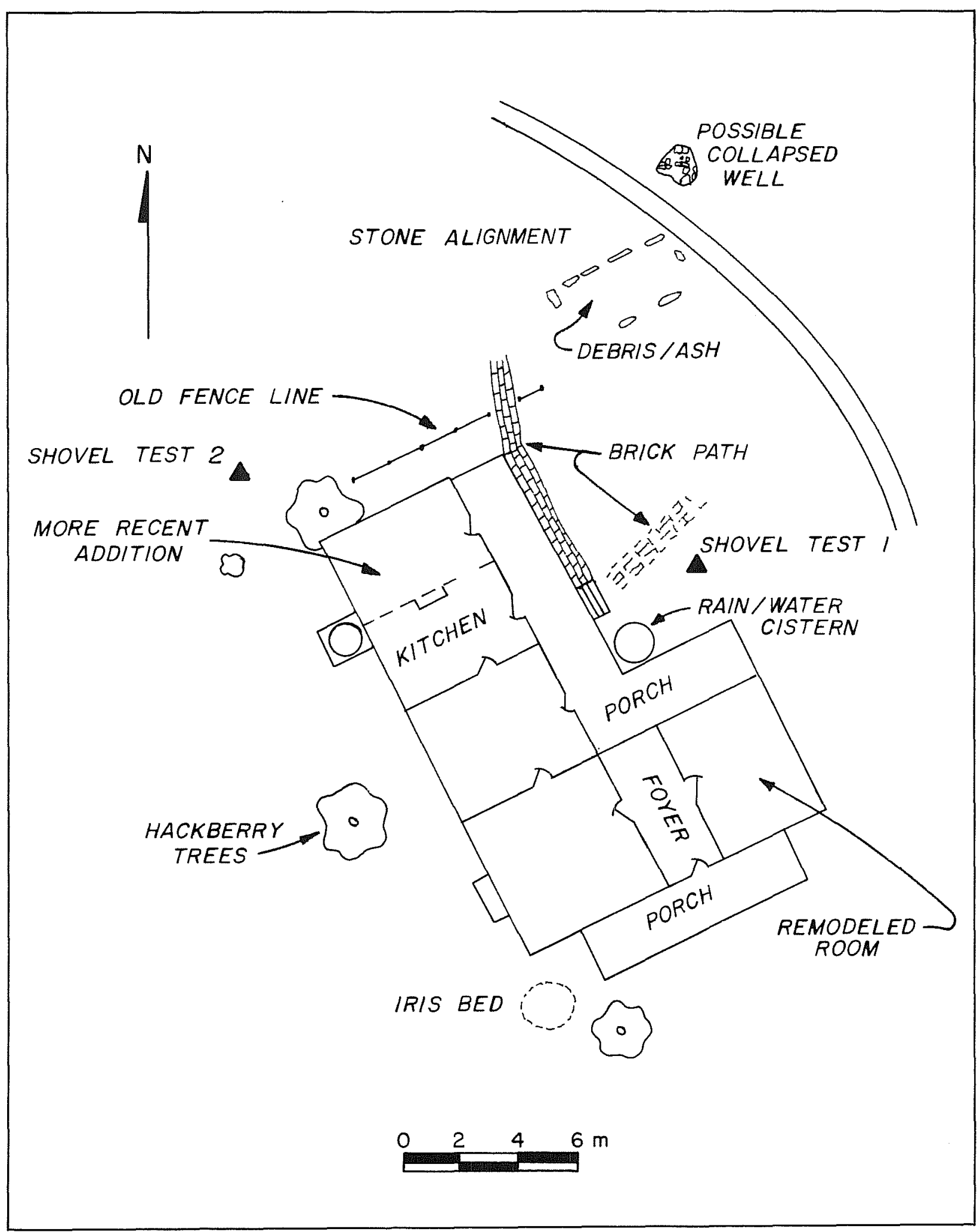

Figure 5. P1an Map of Site 41 BP 275. 


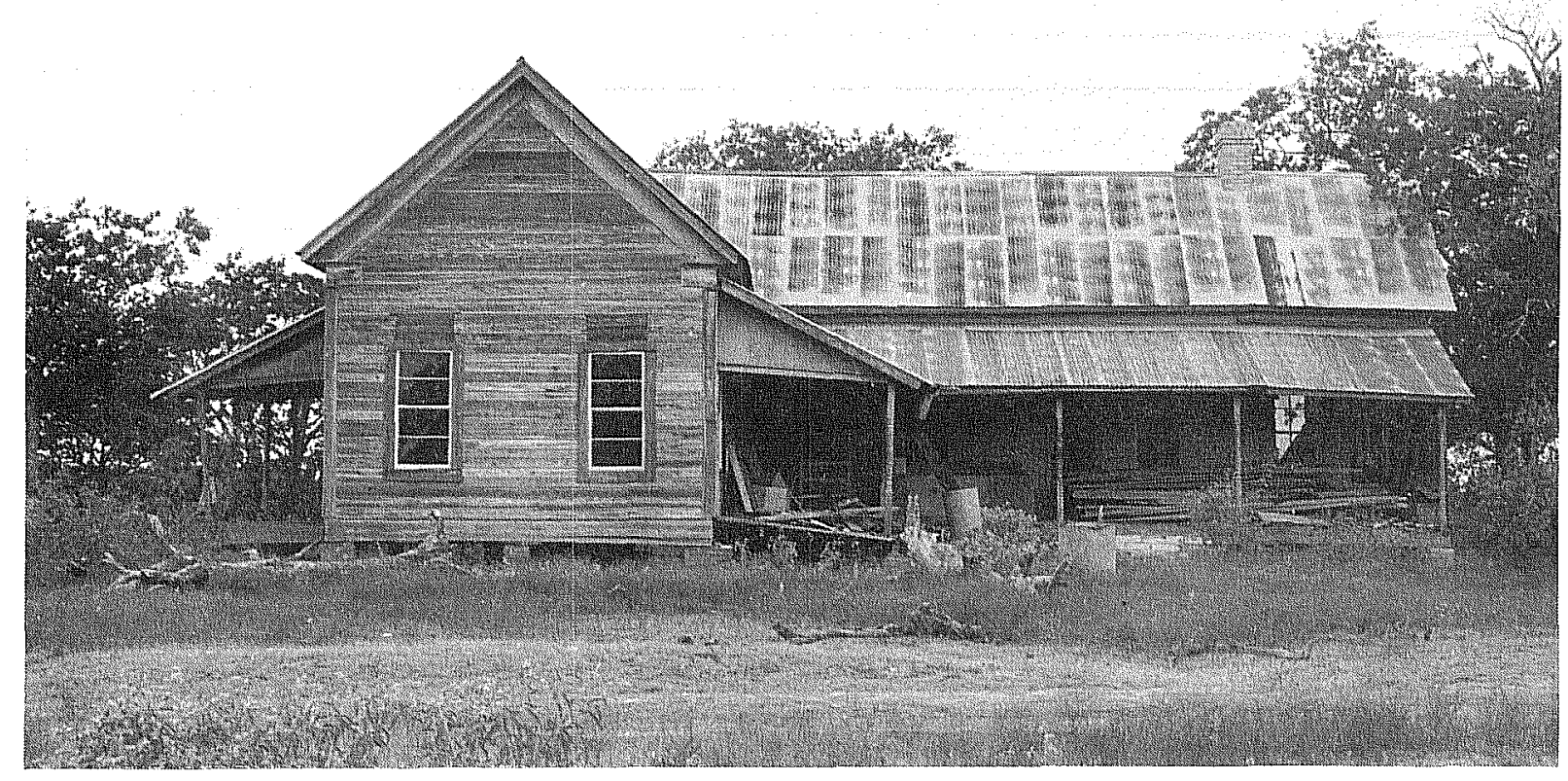

a

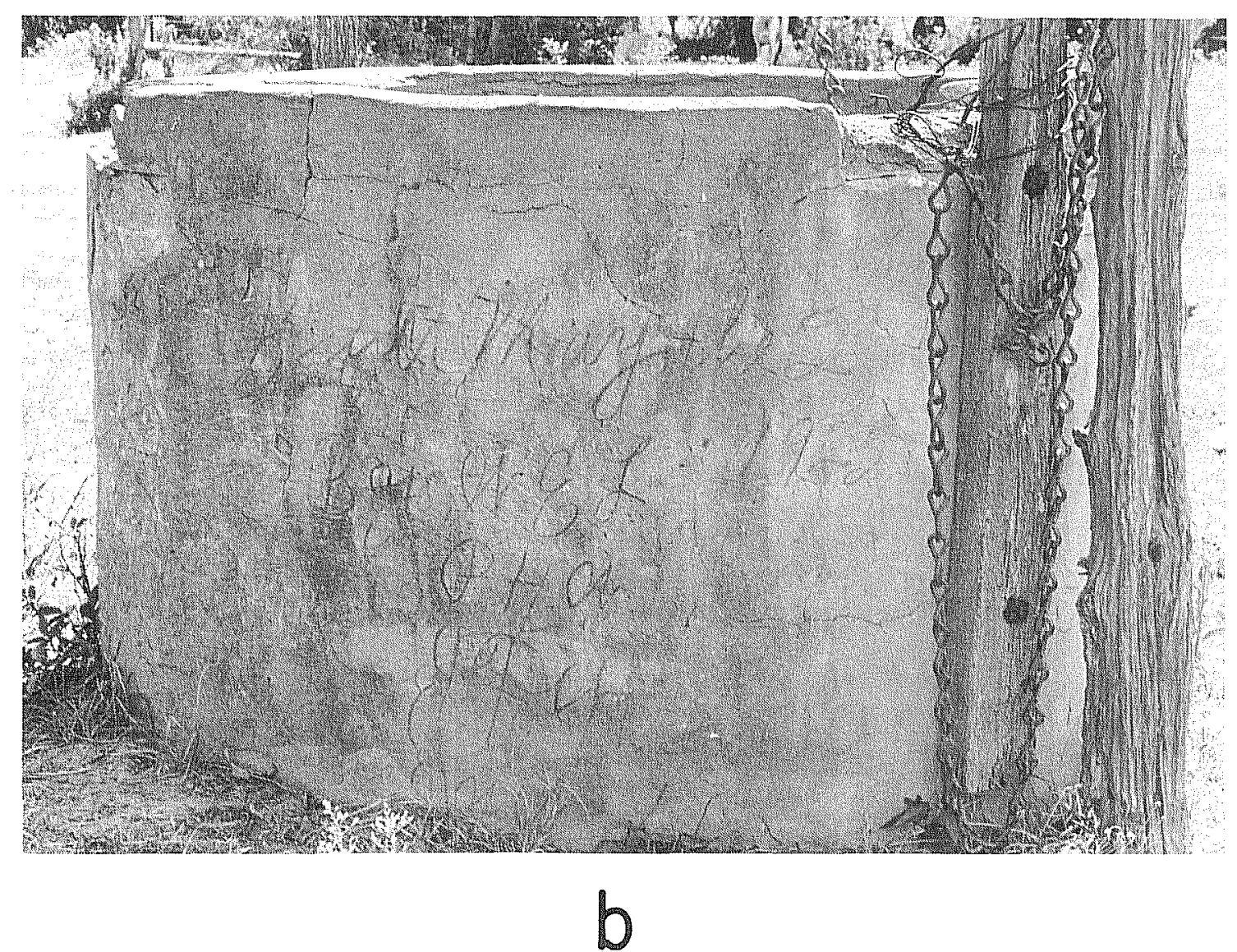

Figure 6. Views of Sites 41 BP 275 and 41 LE 88. a, east side of the wooden frame house at site $41 \mathrm{BP} 275 ; b$, cursive writing on the west side of a well at site 41 LE 88. 
southeastern room has been recently altered with plywood and sheetrock attached to the walls and to the floor. Small metal frame windows have also been added to this room. A brick walkway is by the west side of the house. A rectangular stone alignment with concrete, charcoal, and ash, and burned historic debris consisting of glass, metal, and Butler and standard made brick is northeast of the house, and may mark the location of a former small outbuilding. A raised water tank is along the west side of the house, and a sunken, tin rainwater cistern is by the interior northeast corner of the house. There is a possible collapsed, brick-lined well northeast of the house. Recent farm outbuildings and corrals are north and east of the homestead. The site appears to date to the late $1800 \mathrm{~s}$ and early 1900s. (See the appendix for additional information regarding this site.)

Two shovel tests yielded no cultural materials and showed only $5 \mathrm{~cm}$ of tan sandy clay loam overlying an orange basal clay, and examination showed sheet erosion in the area has exposed the basal clay across much of the site. Very few historic materials were observed at the site, and were mainly concentrated in the debris pile northeast of the house. No collections of artifacts were made.

Though the structural remains at the site are well preserved, the paucity of surface materials and lack of subsurface deposits indicate a low research potential. Therefore site 41 BP 275 is not recommended for designation as a State Archeological Landmark, and is considered to be not eligible for nomination to the National Register of Historic Places.

\section{TRACT 10}

There is a vacant, recent brick house in the west corner of tract 10 that may have been built over part of site 41 LE 88. Along the tributary in the eastern part of tract 10 is a dense brushy area where modern trash has been dumped.

\section{Site 41 LE 88}

Historic site 41 LE 88 (Fig. 7) is on a second terrace that gently slopes westward toward Willow Creek in the western part of tract 10 . The site is on the McDade, Texas, 7.5' USGS topographic map at an elevation of 475 feet to 490 feet above ms T. The area is cleared, and the site is in a barnyard and pasture area immediately north of a vacant, recently built brick house. The cleared pasture has dense short grasses and forbs, scattered mesquite trees, and a sapling pear tree. The ground surface visibility is moderate.

The total site area measures rough7y $56 \mathrm{~m} \times 438 \mathrm{~m}$ and extends east to west along a fence line. The lessee of the property, H. Turnipseed, Jr. (1984), showed us where he had been told that a frame house once stood--on the far west end of the site. A man named Parks Wilson reportedly lived in the frame house. There is a slight rectangular mound at this location and a small amount of structural debris and other historic debris. The site also included a wooden frame outhouse with two seats and vent holes drilled in the sides of the structure in a diamond-shaped design; a square, above-ground 
This page has been

redacted because it

contains restricted

information. 
concrete watering trough with cursive writing on the north rim; and three wells built of brick and concrete, one of which had cursive writing on its west side. The writing on the watering trough and the well was done while the concrete was wet. The writing on the trough is "Built by $\mathrm{PW} \&$ BW Sep 14 1938," and the writing on the well is "Built May the $2 / B y$ WEL 1925/PHW/JFW/JWW" (Fig. 6,b). Kevin Jolly, a field crew member, remembers families in central Texas who farm but are also professional concrete layers during slack periods. These people often sign their names or initials and the date of construction on the wells they build. Recent features at the site are corrals, a garage, and a shed, which have disturbed approximately $15 \%$ of the site, and a stock tank which additionally has destroyed rough 1 y 10 to $15 \%$ of the site.

A shovel test showed sandy loam topsoil at $0 \mathrm{~cm}$ to $10 \mathrm{~cm}$ below the ground surface, sandy clay at $10 \mathrm{~cm}$ to $30 \mathrm{~cm}$, and compact basal clay at $30 \mathrm{~cm}$. No cultural material was observed in the shovel test. A small amount of cultural debris was observed at the site: pieces of modern asbestos tile; fragments of blue, brown, and white glass; sheet tin; and structural lumber. No collections were made. Judging from the small amount of cultural debris and the dates on the well and watering trough, the site generally dates to the 1920s and 1930s. (See the appendix for more information about this site.)

The lack of structural remains (except for an outhouse), site disturbance, and the scarcity of surface and subsurface materials indicate a low research potential. Site $41 \mathrm{LE} 88$ is therefore not recommended for designation as a State Archeological Landmark, and is considered to be not eligible for nomination to the National Register of Historic Places.

\section{TRACT 11}

Tract 11 was wooded with a dense growth of vines and undergrowth. Deep gullies were cut into the loose sandy deposits in the tract. Recent house trailers are in the southwestern part of the tract. No sites were observed in tract 11 .

\section{TRACT 13}

A corral built of railroad timbers with an associated modern trash scatter and a Portland cement foundation with an associated Portland cement and brick cistern and recent trash are located south-southwest of site $41 \mathrm{BP} 276$ in tract 13. A few sherds of purple glass were found in the trash deposits by the cistern, but the other deposits were recent and consisted of aluminum cans and brown beer bottles. These features are considered to be recent and were not recorded as archaeological sites. Uvalde gravel was located in the vicinity of the stock tanks, but none of the lithic material appeared to have been culturally modified. 


\section{Site 41 BP 276}

Site 41 BP 276 (Fig. 8), a historic homestead, is located in a cleared upland pasture on the eastern edge of an upland terrace. The terrace slopes to the east toward a small, unnamed tributary that is now dammed to form a stock tank. The site is in the north-central part of tract 13 on the Elgin East, Texas, 7.5' USGS topographic map. The site elevation is roughly 512 feet above ms 7 . The site is in a sma11 grove of oak, hackberry, and mesquite trees and has a moderate to thick growth of grasses and forbs, and also a few prickly pear cactus. The ground surface visibility is poor to moderate.

The site covers a $22-\mathrm{m} \times 30-\mathrm{m}$ area. Within this area are a collapsed bricklined cistern or we11; an alignment of loose sandstone or limestone slabs; a concentration of brick and sandstone or limestone slabs; a concentration of structural lumber, wire, and nails; a concentration of ash and historic debris measuring approximately $3 \mathrm{~m}$ in diameter; and a dense scatter of glass. The slabs of sandstone or limestone may have once served as a structural foundation.

A shovel test dug into the concentration of ash and historic debris yielded melted glass fragments and a horseshoe, no artifacts were collected. At 0 $10 \mathrm{~cm}$ below the ground surface, the shovel test showed a deposit of fine, light gray, ashy soil; at $10-30 \mathrm{~cm}$ there was a tan sandy clay loam; and at $30 \mathrm{~cm}$ there was a compact red orange basal clay. Additional cultural materials observed on the site surface included blue, purple, and brown bottle glass fragments; window pane glass fragments; an ornate, cast iron stove piece; whiteware ceramic sherds; and a metal file. No materials were collected from the site. The materials observed indicate that the site dates to the late 1800s or early 1900s. (See the appendix for additional information about this site.)

On the basis of the materials observed, site 41 BP 276 is assessed as having a low research potential. Therefore the site is not recommended for designation as a State Archeological Landmark, and is considered to be not eligible for nomination to the National Register of Historic Places.

\section{TRACT 15}

Much of tract 15 has deposits of mounded blown sand with a growth of tall bunch grass. A trash dump with structural lumber, household items, and bricks is in a gully in the southeastern part of tract 15, and extends into the southwestern part of tract 23 and the north-central part of tract 22. Because these materials are recent, other than a few sherds of purple bottle glass, the dump was not recorded as an archaeological site.

\section{Site 41 BP 277}

Site 41 BP 277 consists of a brick we11 located on a highland terrace in the northeastern part of tract 15 . The area is located on the McDade, Texas, 7.5' USGS topographic map at an elevation of 510 feet above ms1. The well is located beneath a low-lying juniper tree in a cleared pasture. The 


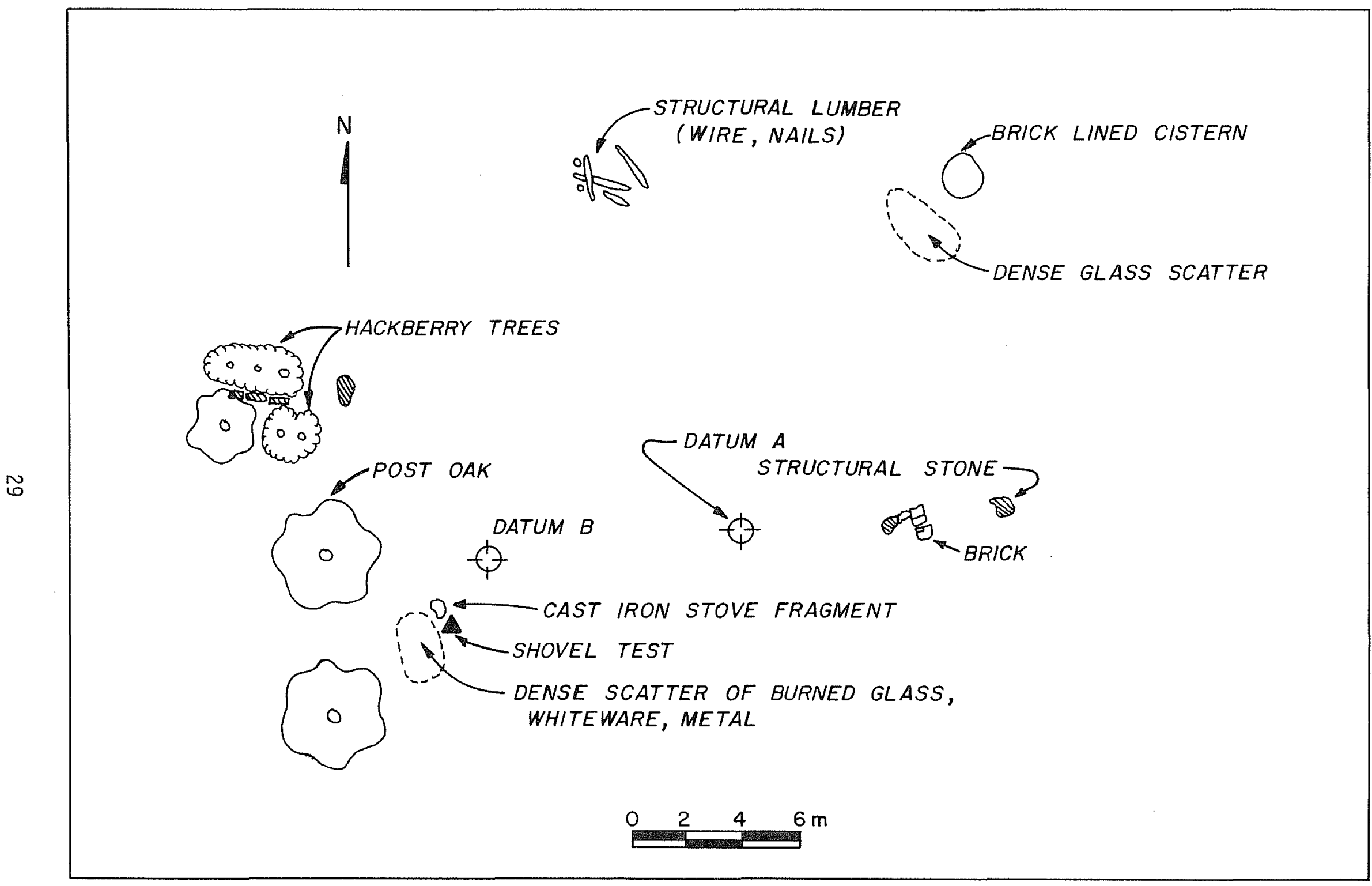

Figure 8. Plan Map of Site 41 BP 276. 
predominant ground cover is tall grasses and forbs which afford poor to moderate ground surface visibility. There is a belt of juniper trees extending north-south along the east fence line. Blown sand deposits have accumulated in this area, and erosional cuts occurred north of the site in the blown sand.

The site size is roughly $3 \mathrm{~m} \times 3 \mathrm{~m}$, allowing for a $1-\mathrm{m}$ border around the we11, which measures $1 \mathrm{~m}$ in diameter. The wel1 is built of straight, rather than formed, machine-made brick, and a piece of sheet tin covered the wel1 opening. No other features or structures were found associated with the we11, though there were a few bricks with attached mortar found in a small gully approximately $25 \mathrm{~m}$ north of the we17. The bricks may have been deposited in the gully to retard erosion; a practice which was frequently observed in the survey area. A7so observed were the remains of a wooden structure with brick and recent debris in a large gully in the southeast corner of the tract and in the adjoining southwest corner of tract 23. Perhaps there was a structure associated with the well that was torn down and dumped into the gully, but there were no indications of a habitation in the vicinity of the well. No collections were made from the site.

Because the subsurface deposits of the site could be observed in numerous nearby erosional cuts, no shovel tests were dug. The area has deposits of tan aeolian sand of varying depths overlying a compact basal clay. The lack of associated cultural material makes it difficult to date this site. The machine-made brick used to construct the we11, however, suggests that it dates to the turn of the century or later. (See the appendix for more information on this site.)

The research potential of site $41 \mathrm{BP} 277$ is considered to be low because of the lack of cultural deposits and associated features with the well. The site is not recommended for designation as a State Archeological Landmark, and is considered to be not eligible for nomination to the National Register of Historic Places.

\section{TRACT 16}

In the north-central part of tract 16 is a deteriorating, abandoned, two-room wooden frame house built of sheetrock and lumber, with a poured concrete base, and the wooden frame of an associated outbuilding. A collapsed lumber frame shed is a short distance east of the house. Southwest of the house and outbuilding is a recent trash dump. A lumber frame car shed is in the central part of the tract. These features are considered to be recent and were not recorded as archaeological sites. Sand mining appears to have occurred in the central and western parts of this tract. In the southcentral part of the tract there is a deep gully which extends into the northeastern part of tract 2. Deposits of sandstone are exposed by the gully. Bricks were found in the gully and appear to have been originally deposited in an attempt to halt erosion in this area. 
Site 41 BP 278 is a historic debris scatter located on a gentle eastern slope on a high terrace west of a small, intermittent tributary. The site is in the northwestern part of tract 16 on the Elgin East, Texas, 7.5' USGS topographic map. The site elevation is 545 feet above ms 7 . The debris occurred in a cleared pasture with a scanty cover of short grasses and forbs, prickly pear cactus, and mesquite trees, which provides excellent ground surface visibility. The area is subject to sheet wash, and is quite deflated. The compact clay substrate is exposed across much of the site.

The site covers a $10-\mathrm{m} \times 20-\mathrm{m}$ area. A 7 -cm-deep shovel test showed $5 \mathrm{~cm}$ of tan sandy loam on compact red orange basal clay. No cultural materials were observed in the shovel test. Debris observed at the site consists of a crockery sherd, two purple glass fragments, two thick plain whiteware sherds, a fragment of aqua bottle glass, two fragments of brown bottle glass, and a clear glass bottle neck with a seam extended from the neck to the 1 ip. No materials were collected from the site.

Site 41 BP 278 is roughly $100 \mathrm{~m}$ east of the site of the former Mt. Pleasant church and school which functioned during the $1880 \mathrm{~s}$ and $1890 \mathrm{~s}$, and burned to the ground during the spring of 1984 (Kelly and Roemer 1981:14-18; Brown 1986; Taylor, Fox, and Cox 1986). It is possible that the debris from this site is associated with the Mt. Pleasant church and school. The site generally dates to the late 1800 s and early 1900s. (See the appendix for additional information.)

The site appears to have very limited research potential because of the sparse and shallow nature of the cultural remains. For this reason, it is not recommended for designation as a State Archeological Landmark, and is considered to be not eligible for nomination to the National Register of Historic Places.

\section{TRACT 20}

In the east-central and southern parts of tract 20 are deep gullies. Deposits of yellow sandstone or siltstone and ferruginous sandstone are exposed by gullies in the southwestern part of the tract. The eastern part of tract 20 has cleared pasture with scanty vegetation, and the central and western parts of the tract are heavily wooded. A vacant house trailer with associated outbuildings and a garden plot are in the north-central part of tract 20 .

\section{Site 41 LE 85}

Site 41 LE 85 is a thinly dispersed upland terrace scatter of presumably prehistoric and historic debris. It is on a gentle western slope in the southeastern part of tract 20 on the McDade, Texas, $7.5^{\prime}$ USGS topographic map. The site elevation is 482 feet above msl. The pasture in which the site is located was root plowed for coastal Bermuda grass approximately 12 years ago, according to the lessee of the property. The area has a sparse 
cover of short grasses and forbs, prickly pear cactus, and sma11 mesquite trees, and is subject to sheet wash. The ground surface visibility is good to excellent. On the west side of the site is a deep gully that cuts across the central part of the tract, and a small, unnamed tributary with a dense growth of oak trees.

The site covers a $36-\mathrm{m} \times 50-\mathrm{m}$ area. No evidence of structures or other features were observed at the site. On the ground surface were fragments of green bottle glass and brown beer bottle glass, plain whiteware ceramic sherds, a crockery sherd, and also a chert uniface fragment (the only lithic cultural material observed) None of these materials were collected. A shovel test showed $15 \mathrm{~cm}$ of sandy loam above a compact, red sandy clay subsoil. No cultural material was recovered from the shovel test. It is possible that this site is a trash disposal area associated with site 41 LE 86 or with another nearby homestead. The lessee of the property, L. S. Clark (1984), told the archaeologists that a former homestead (a house and cistern) once occupied by the Voydts (spelling uncertain) was located to the east of site 41 LE 85 . This 1ocation was outside the survey area, however, and was not investigated. The cultural debris can only be assigned to a wide time range from the late 19th century into the 20th century. (See the appendix for more information about this site.)

The research potential of site 41 LE 85 appears to be low because of the sparse, shallow, and disturbed nature of the deposits. The site is not recommended for designation as a State Archeological Landmark, and is considered to be not eligible for nomination to the National Register of Historic Places.

\section{Site 41 LE 86}

On an upland terrace is a historic homestead, 41 LE 86 , known as the 01d Mundine Place according to the lessee of the property and his wife, Mr. and Mrs. L. S. Clark, who also provided additional information about the site. The site is located in a cleared pasture that was root plowed for coastal Bermuda grass in the east-central part of tract 20 on a divide between two sma11, intermittent tributaries east and west of the site. The western tributary is located in a deep gully. The location of the site is on the McDade, Texas, $7.5^{\prime}$ USGS topographic map at an elevation of 530 feet above ms 1. Sparse short grasses and forbs and scattered mesquite and hackberry trees grow in the area, which provide good to excellent ground surface visibility. An east-west alignment of juniper trees grows along the north side of the former location of a L-shaped frame house that is represented by loose foundation stones. Sheet erosion is occurring at the site, and much of the site area is exposed clay subsoit.

The site covers a $20-\mathrm{m} \times 30-\mathrm{m}$ area. Loose, rough sandstone blocks form the house foundation, and scattered brick is on the south side of the foundation with other historic debris. A tin-capped cistern is located at what would have been the north-central side of the house. A shovel test showed $30 \mathrm{~cm}$ of sandy loam over compact, red orange sandy clay, and produced no cultural green, brown, and clear glass fragments; a broken glass Mason jar lid; whiteware sherds, one of which had a brown leaf applique; crockery sherds; 
and also brick, structural lumber, and tin. These materials date to the early 1900s.

The structure was built in ca. 1912. Mrs. Clark's mother, Annie Mundine, lived in the house as a child along with 12 other children and her parents. The L-shaped house had five rooms, one of which had a fireplace, and the outside of the house was boxed with siding. The family moved from the house in order to be nearer to the local school. The house was abandoned in 1928, after being leased to other people, and was disassembled in 1945. The lumber and rock from the house were used to build a barn at Elgin, Texas (Clark 1984). (See the appendix for more information about this site.)

Site 41 LE 86 is assessed as having a low research potential based upon the lack of structural remains, the shallow, disturbed nature of the cultural debris, and the information provided by Mr. and Mrs. Clark. The site is therefore not recommended for designation as a State Archeological Landmark, and is judged to be not eligible for nomination to the National Register of Historic Places.

\section{TRACT 21}

A wooden frame shed covered with sheet tin, which appeared to date to after 1930 , is in the northeastern part of tract 21 . Modern glazed brick and tile pave the ranch road from Highway 696 to the shed. Numerous bricks have been placed in this area possibly to retard erosion. A large peach tree is located by the brick concentration, but no evidence of cultural materials or features was found in this vicinity. Another, smaller concentration of brick is in the east-central part of the tract on the west and south sides of a large, irregularly shaped stock tank. This brick concentration was used to pave a portion of the ranch road here as we1l as to help retard erosion. A fragment of what appeared.to be a fire-cracked quartzite cobble was found in the northwestern part of the tract, an area subject to sheet erosion. Since no other cultural materials were found associated with the quartzite, it was not recorded as an archaeological site. In the northeast part of the tract, Uvalde gravel is exposed by sheet wash erosion.

\section{TRACT 22}

Tract 22 has been cleared, and an occupied house, house trailer, and outbuildings are in the southeastern part of the tract. The western part of the tract appears to have been plowed, and is covered with deposits of sand. Uvalde gravel and also basal clay are exposed by sheet wash erosion in parts of the site. Gullies are present along the southern side of the tract where there is a sma11 tributary. 

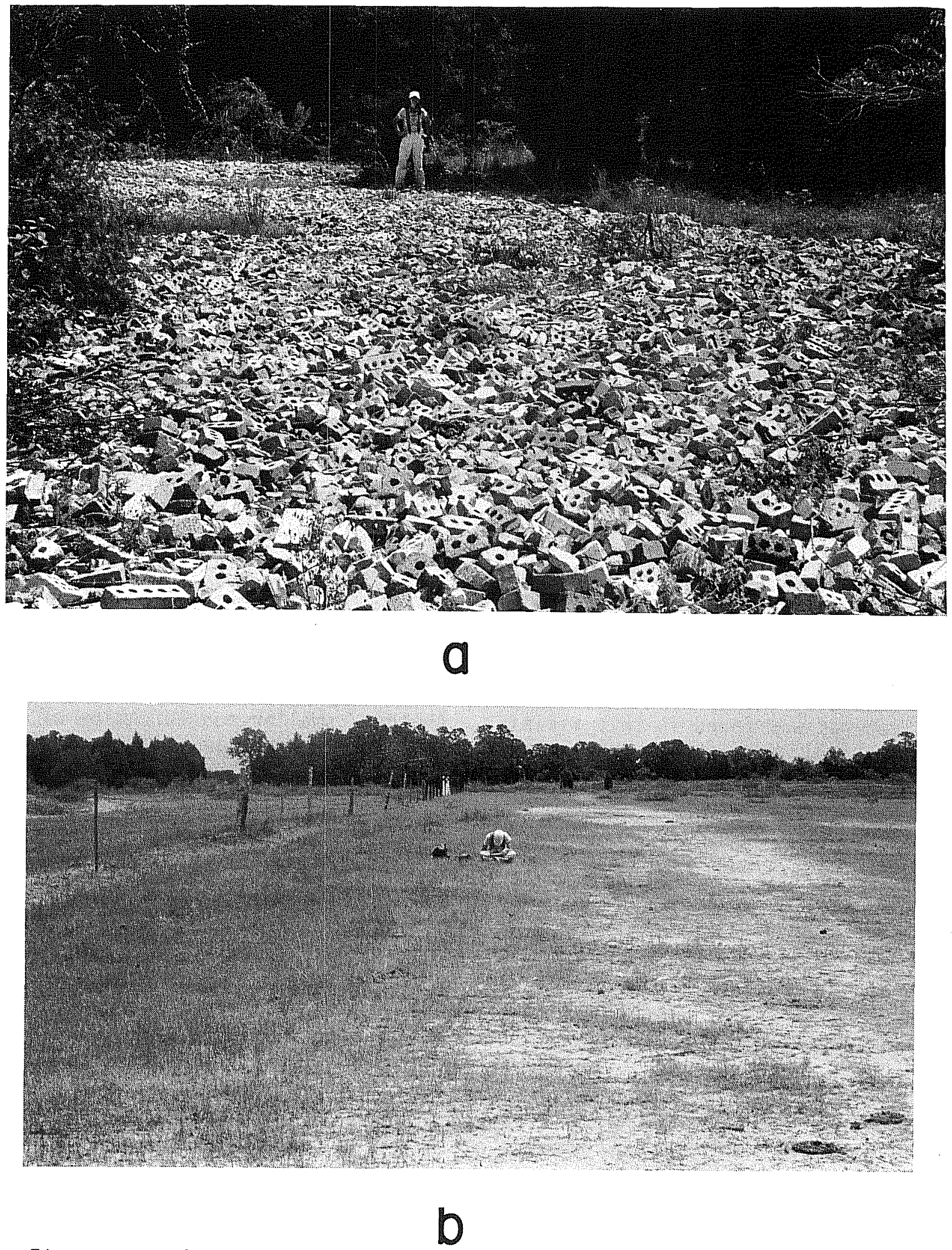

Figure 9. Views of a Deposit of Butler Bricks and Site 41 BP 273. a, an extensive deposit of Butler bricks in a creek bed in the northcentral part of tract 21, facing east; $b$, the eroded surface of site 41 BP 273. 
An undated, presumably prehistoric, highland Tithic scatter (Fig. 9,b), designated as site $41 \mathrm{BP} 273$, is on top of a terrace near a gentle eastern slope above a sma11, intermittent stream that has been dammed to form two stock tanks. The site is located in the central part of tract 22 on the McDade, Texas, 7.5' USGS topographic map at an elevation of 535 feet above ms7. On the east side of the site is a fence line and a pipeline, and on the south side is a ranch road. The site may have been disturbed by the construction of the fence and pipeline. The site is located in an improved pasture with a sparse growth of grass and forbs which allows excellent ground surface visibility. The immediate area of the site is deflated, and may have also been bladed during the fence and pipeline construction. The basal clay is exposed across most of the site.

The site covers a $16-\mathrm{m} \times 30-\mathrm{m}$ area along the east side of the fence 1 ine. A shovel test produced no cultural material and showed only approximately $1 \mathrm{~cm}$ of tan sandy loam above compact orange sandy clay. Surface materials observed were two chert primary flakes (one may have been thermally altered) and one petrified wood biface fragment. No collections were made at the site.

The apparent lack of subsurface deposits, the lack of temporal diagnostics, and the diffuse and sparse nature of the materials at site 41 BP 273 suggest that additional investigations would not recover more data. Therefore, the site is not recommended for designation as a State Archeological Landmark, and is considered to be not eligible for nomination to the National Register of Historic Places.

\section{TRACT 23}

A vacant, recently built brick house is located in tract 23 . It was not recorded as an archaeological site.

\section{Site 41 BP 274}

A historic site, 41 BP 274 (Fig. 10), is in an improved pasture in the southcentral part of tract 23 on the gentle southeastern slope of a highland terrace above a sma11, intermittent stream. The site is located on the McDade, Texas, 7.5' USGS topographic map at an elevation of 545 feet above ms 1. The area has a light to moderate growth of grasses and forbs, prickly pear cactus, mesquite, juniper, and oak trees. The site area is very deflated and subject to sheet erosion, providing good to excellent ground surface visibility. The compact clay subsoil is exposed across much of the site. The site includes the remains of two divided, split-log corncribs, a collapsed cistern or we11, and historic debris. The site covers a $16-\mathrm{m} x$ 44-m area.

Corncrib A, the southern corncrib, is the better preserved of the two structures, with sides formed of stripped, unhewn logs with saddle notching (Fig. 11,a). The corncrib appears to have been constructed without using 


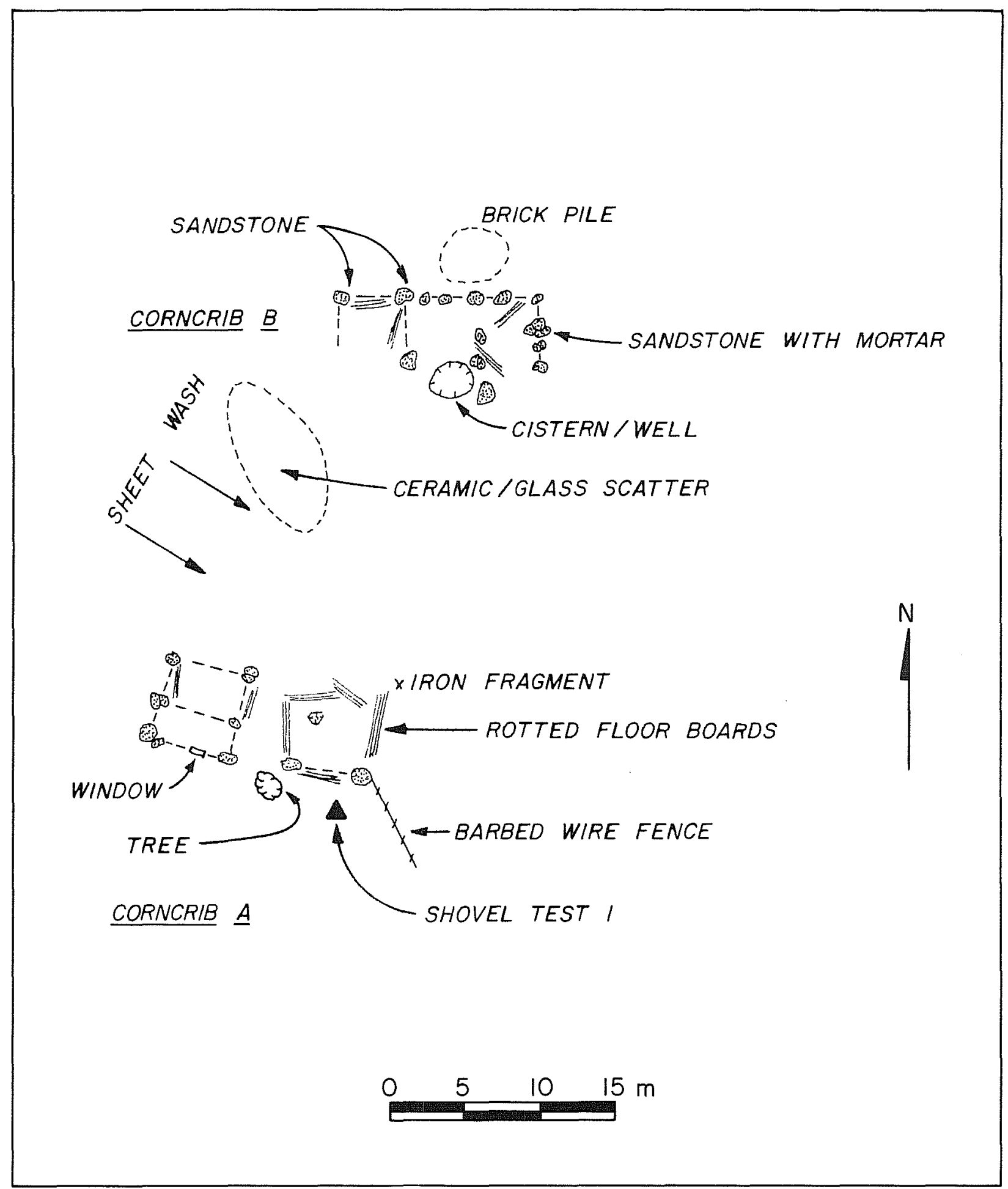

Figure 10. Plan Map of Site 41 BP 274. 


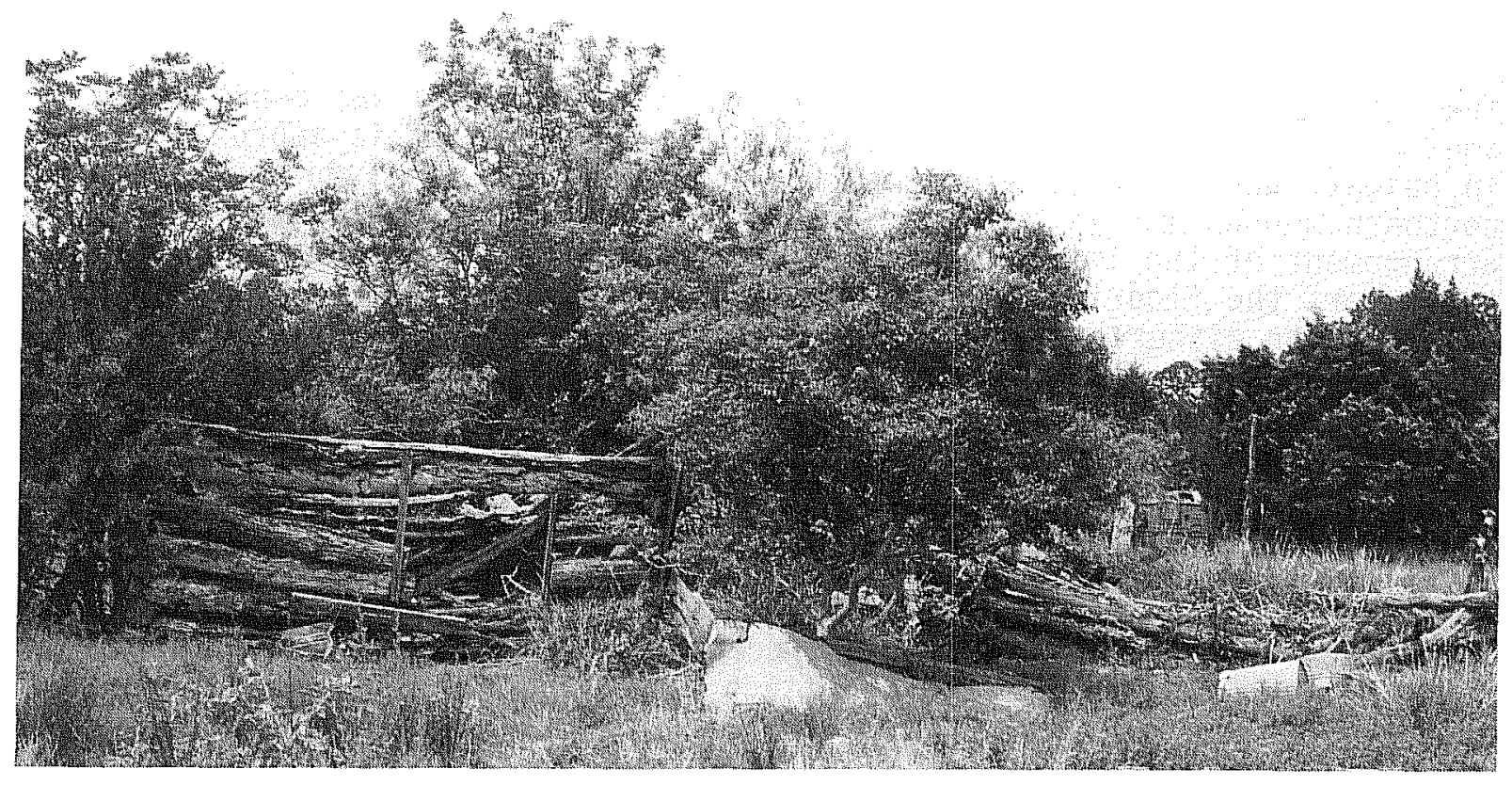

a

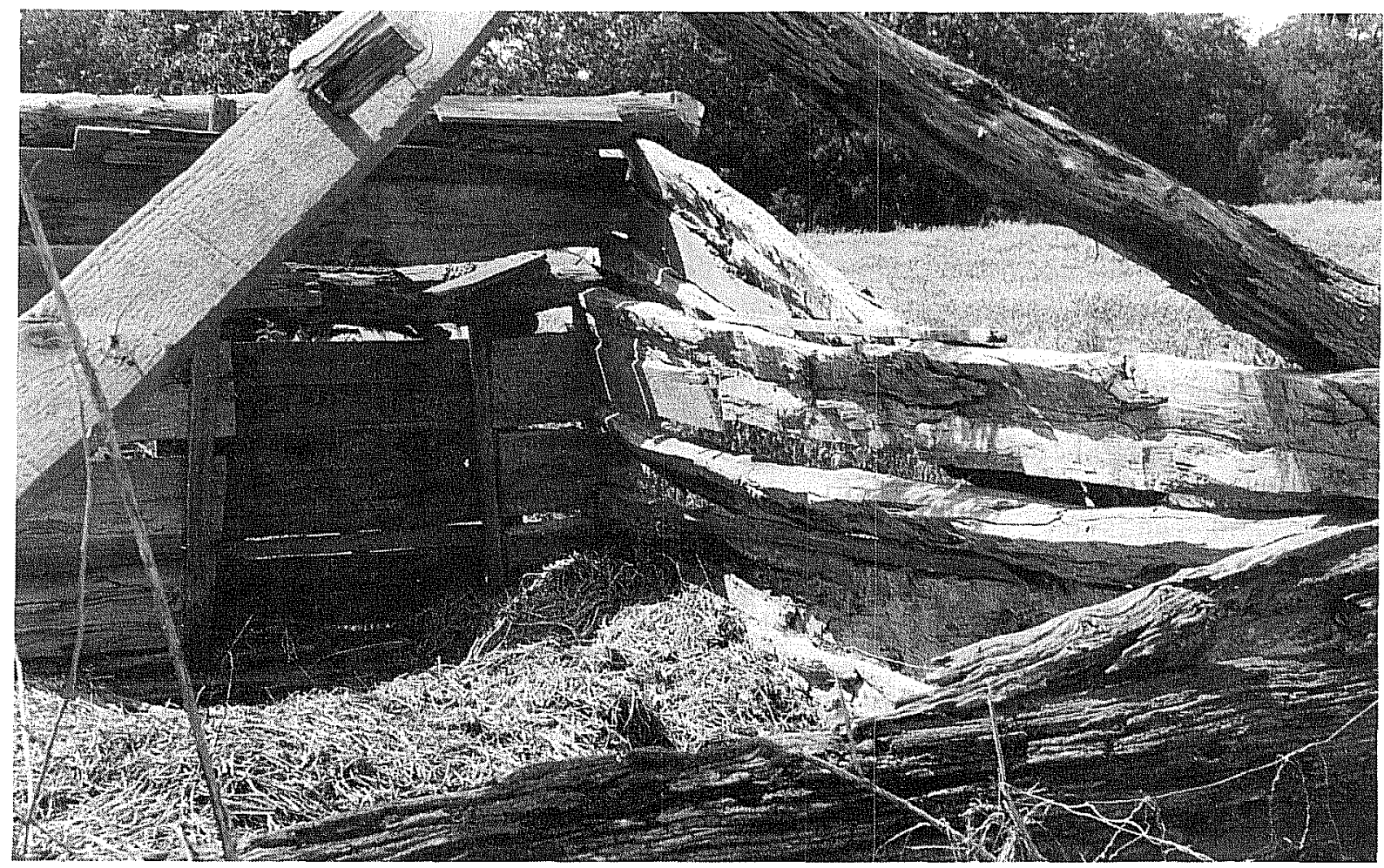

b

Figure 11. Views of Sites 41 BP 274 and 41 LE 87 . a, the south side of Corncrib A at site $41 \mathrm{BP} 274 ; \mathrm{b}$, the doorway in the east wing of the corncrib at site 41 LE 87 , facing northwest. 
nails to secure it. There is a lumber floor remnant in the structure. The frame for an opening on the south side of the west wing was constructed with square cut nails and round wire nails. The western wing is approximately $2 \mathrm{~m}$ in height, and the east wing has mainly collapsed. This corncrib, like the northern corncrib, is set on a loose, rough sandstone foundation. The arrangement of the sandstone foundation blocks and of the wooden beams used to support the flooring in both wings shows that three cross beams supported by blocks on either end extended the width of each wing. Fragments of clear and purple pressed glass, a square cut nail, and two round wire nails (Table 6) were collected from an eroding debris scatter on the south side of the west wing of the corncrib.

Corncrib B, the northern corncrib, has collapsed, with little of the structure remaining. A portion of the west wing is preserved, but the east wing is represented only by the loose, rough sandstone blocks used for the foundation. This corncrib is constructed of square hewn timbers with square notching, and nails were used to attach the timbers. Round wire nails were observed by the notching and ends of the timbers, but square cut nails were along the sides of the wings. Two square cut nails and a round wire nail were collected from the vicinity of the structure (Table 6). A cistern, or wel1, is located very close to the south side of the northern corncrib, which suggests that the cistern may have been constructed either before the corncrib was built, or possibly after the corncrib was abandoned.

Both corncribs are approximately $4 \mathrm{~m} \times 10 \mathrm{~m}$. The individual wings are approximately $4 \mathrm{~m}^{2}$, and the "dogrun" between the wings is approximately $1.5 \mathrm{~m}$ to $2 \mathrm{~m} \times 4 \mathrm{~m}$. The different appearance of the two corncribs suggests they were built at different times. A concentration of historic debris with ceramics and glass, exposed by sheet wash, is present between the two corncribs. Sherds of whiteware, yellow ware, porcelain, and Bristol Glaze stoneware; glass fragments of clear bottles; a milk glass jar lid liner; a purple bottle base; purple and clear pressed glass; a green canning jar 1jd; an unidentified gold object; brown bottles; and thick plate glass were collected from this debris concentration (Table 6; Fig. 12,a-g). These materials generally date from 1885 to the 1920s. There was a concentration of brick by the north side of the northern corncrib. Sheet metal, baling wire, and sandstone are scattered predominantly across the northeastern part of the site. Two sandstone blocks northwest of the site were first thought to be part of a foundation for a third corncrib, but further investigations showed that they were not part of a structure. Several wire fences are in the vicinity of the site, but it is not known if they are contemporary with the site. The presence of occupational debris suggests that the site may have once been a homestead, but no traces of a house or other outbuildings were found. (See the appendix for additional information regarding this site.)

The surface soil is a tan sandy loam that overlies a compact, red basal clay. A single shovel test yielded no cultural materials and showed less than $1 \mathrm{~cm}$ of sandy loam overlying the clay subsurface.

The apparent lack of subsurface deposits, the poorly preserved condition of the corncribs, and no other structural remains associated with the corncribs, indicate that site $41 \mathrm{BP} 274$ has a low research potential. The site is 

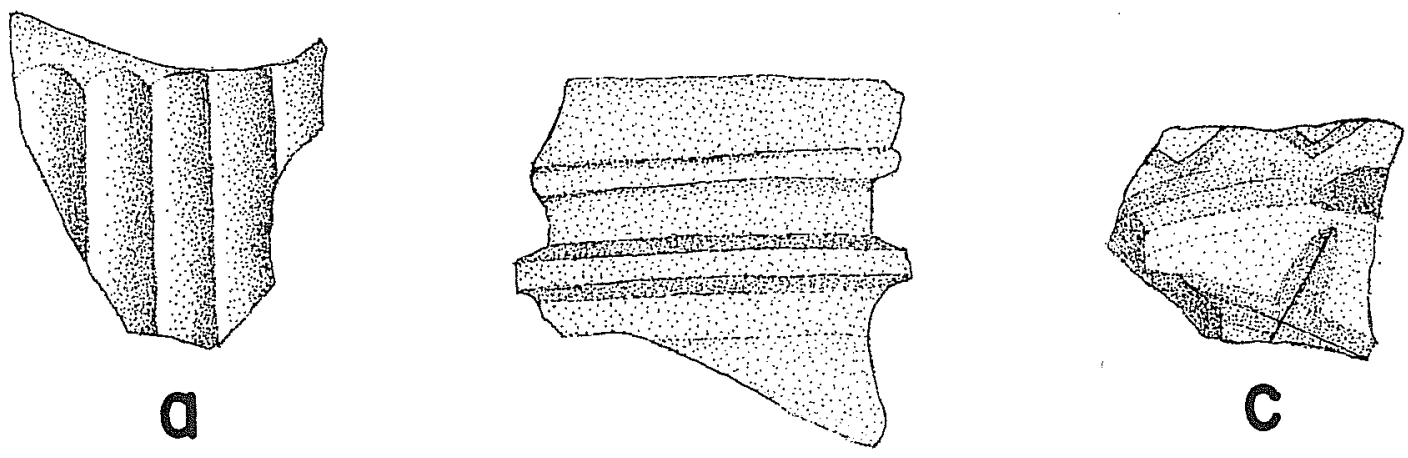

b
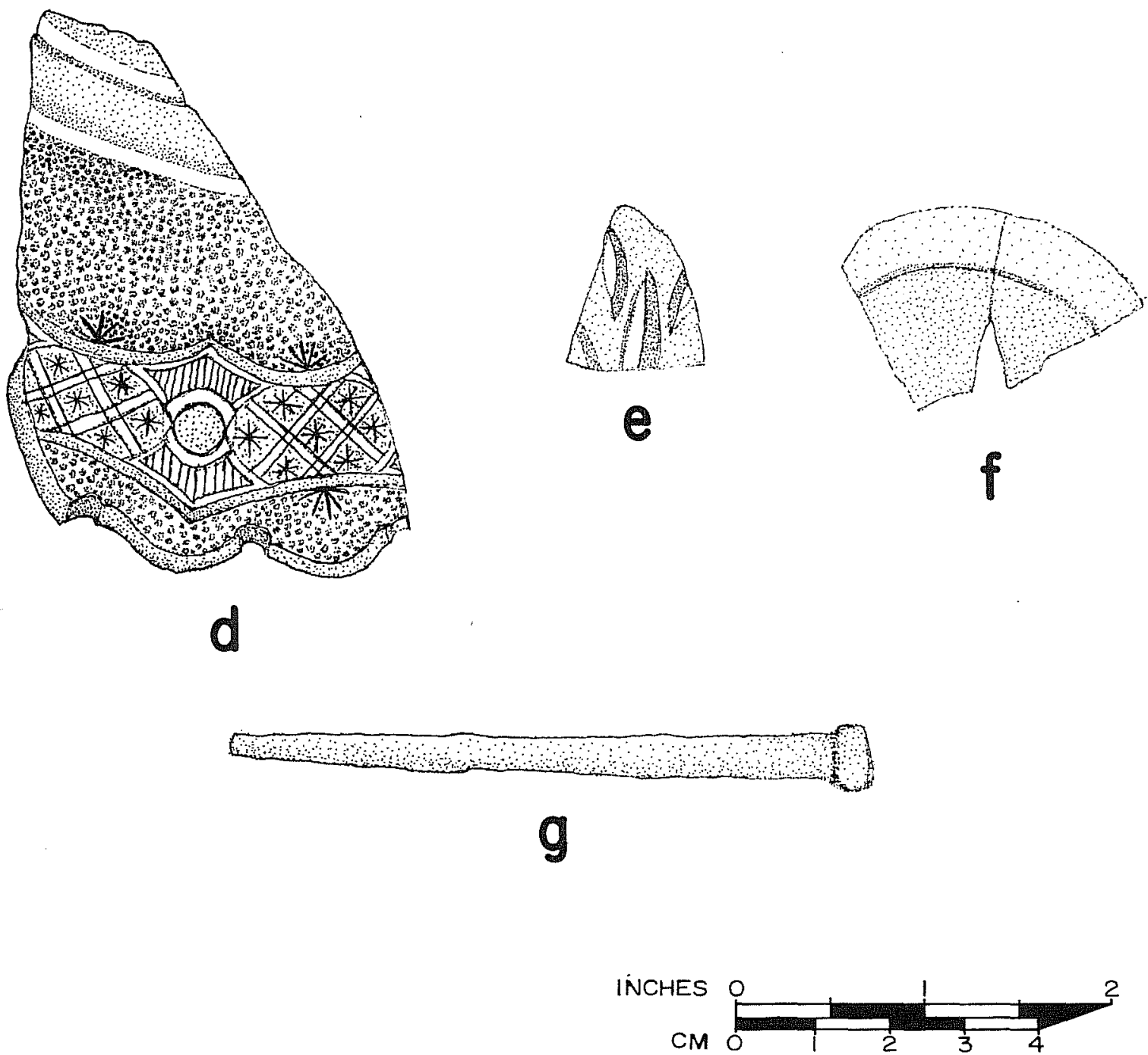

Figure 12. Artifacts from Site 41 BP 274. a, clear glass fragment with fluted design; b, clear glass fragment from a screw top jar; c, clear pressed glass fragment; d, purple pressed glass fragment from a vessel 1id; e, purple pressed glass fragment; $f$, milk glass jar lid Tiner fragments; $g$, square cut nail. 
therefore not recommended for designation as a State Archeological Landmark, and is considered to be not eligible for nomination to the National Register of Historic Places.

\section{TRACT 25}

Tract 25 is overgrown by dense vegetation and is covered by deep deposits of mounded sand. A vacant, recently built house and house trailer are in the east-central part of the tract. There is a modern trash dump in the northeast part of the tract. Neither the recent structures nor the trash dump were recorded as archaeological sites.

\section{TRACT 26}

A vacant, recently built brick house and associated outbuildings, including a swimming pool and a stock pond, are located in tract 26. L. C. Hobbs (1984), who formerly resided on this tract, told the archaeologists that the modern structures are located where an old wooden plank house used to be. No traces of this structure were found, however. A recent historic trash dump is located in the southwest corner of the tract. Neither the modern structures nor the trash dump were recorded as archaeological sites.

\section{TRACT 27}

Uvalde gravel is exposed in tract 27 . A recent trash dump is in the northcentral part of this tract. It was not recorded as an archaeological site.

\section{Site 41 LE 87}

Historic site 41 LE 87 is a partially collapsed corncrib (Fig. 11,b) located on a highland terrace in tract 27 on the Beaukiss, Texas, $7.5^{\prime}$ USGS topographic map at an elevation of 510 feet above ms 7 . The site is east and southwest of two sma11, unnamed tributaries. This area has been cleared and plowed. The vegetation observed was a sparse growth of short grasses and forbs and scattered mesquite and oak trees. The ground surface visibility was moderate.

The site area is roughly $2.2 \mathrm{~m} \times 4.9 \mathrm{~m}$ and includes the immediate vicinity of the corncrib. The dog-run corncrib has partially collapsed, and the roof is missing from the structure. It was constructed of half-log beams with semilunate notching. Concrete had been used for chinking in a few places on the sides of the corncrib. The corncrib is located south of an abandoned wooden frame house. The present house has a square shape, horizontal siding, and a corner porch. The house probably dates to the 1930s judging from the architecture, and appears to have been moved to this location and placed on a foundation where a former structure, perhaps another house, once stood. The contours of the house foundation did not completely match those of the present house. No traces of the original structure were observed. The 
corncrib was probably part of a rural homestead which included the structure that probably once stood where the modern frame house is now.

The shovel test showed $20 \mathrm{~cm}$ of tan sandy loam on compact, red sandy $\mathrm{clay}$ and produced no cultural material. Split and hewn logs, structural lumber, barbed wire, round nails, chicken mesh wire, a heavy iron chain, and two Mode]-T truck tires were observed in the vicinity of the corncrib, but no materials were collected. Near the corncrib was a recently built tree house constructed of tin and lumber which may have been obtained from the corncrib. No dates could be assigned to this site due to the lack of chronologically diagnostic artifacts. (See the appendix for additional information.)

This site is judged to have a low research potential based on the absence of features associated with the corncrib and the scarcity of surficial and subsurface deposits associated with the corncrib. Also, the house originally associated with the corncrib appears to have been removed. Little additional information could be gained from further investigations at the site. Site $41 \mathrm{LE} 87$ is therefore not recommended for designation as a State Archeological Landmark, and is judged to be not eligible for nomination to the National Register of Historic Places.

\section{TRACT 29}

The foundations of two structures made of modern Portland cement, and aTso a wooden outbuilding (which appears on the $7.5^{\prime}$ USGS McDade, Texas, topographic map) were observed in the south-central part of tract 29. Materials observed in this area and the type of construction used for these structures indicate that this is a modern site dating to the 1940s or 1950s. It was therefore not recorded as an archaeological site.

\section{TRACT 30}

\section{Site 41 LE 89}

Historic site 41 LE 89 is possibly a rural homestead, located in the southeastern part of tract 30 . The area is located on the McDade, Texas, $7.5^{\prime}$ USGS topographic map at an elevation of 522 feet above ms 1 . The site is east-southeast of a sma11, intermittent tributary on a third terrace. The intact portion of the site is in a grove of pin oak saplings within a plowed field. The site area within the oak grove has short grasses and scattered juniper trees, with moderate ground surface visibility, and the field had been recentiy plowed at the time of the survey, providing excellent surface visibility. Gopher mounds were present at the site.

The site covers an approximately $40-\mathrm{m} \times 50-\mathrm{m}$ area. The area includes a bel1shaped brick cistern with sandy mortar, structural lumber which had been thrown into the cistern, a block of sandstone, brick footing for a concrete windmill pad near the cistern, metal parts from a collapsed windmi11, sheet tin, and bed springs. No standing structures were observed. 
A shovel test showed $35 \mathrm{~cm}$ of undifferentiated fine sandy loam on compact, sandy basal clay. No cultural materials were recovered from the shovel test. Historic debris were scattered in the field surrounding the oak grove. The materials observed, but not collected, were plain whiteware sherds, crockery sherds, modern glazed tile, bottle glass fragments (one bottle neck had a twist top, another had a cork top and a seam extending halfway up the side of the neck), metal that appeared to be Mason jar lid fragments, and brick with attached mortar. The cultural debris observed at the site generally dates to the late 19th century and into the 20th century. (See the appendix for more information.)

The lack of structural remains and the paucity of undisturbed subsurface cultural remains at site 41 LE 89 indicate a low research potential. For this reason, it is not recommended for designation as a State Archeological Landmark, and is considered to be not eligible for nomination to the National Register of Historic Places.

\section{TRACT 31}

Modern trash, not recorded as an archaeological site, has been dumped in the southeast and southwest corners of tract 31 which is predominantly a cleared pasture with a few dense stands of trees. Sma11 rodent burrows and animal dens are present throughout the tract.

\section{SUMMARY}

On the basis of survey data, which has been detailed for each site in this report, none of the 14 sites located during the phase IV survey are recommended for designation as a State Archeological Landmark, and none are considered eligible for nomination to the National Register of Historic Places. For the reasons stated with each site description, all the sites identified in the survey area are considered to have a low research potential.

The three prehistoric sites are all upland sites located near small tributaries. All are sparse, shallow lithic scatters with chipping debris and lack chronologically diagnostic tools. These sites resemble those found by other surveys in this region, as noted by Brown (1986, citing Nightengale and Jackson 1983:21, Ske1ton and Freeman 1979:52-53, and Kenmotsu 1982:53-55). It is not known if the lithic materials found at these sites were manufactured from the locally occurring lag deposits of Uvalde gravel which were observed in several of the surveyed tracts.

No historic sites were located in the survey area that predate the late 1800s. Kelly and Roemer (1981) and Brown (1986) also did not find any earlier historic sites in this vicinity. As Brown (1986) notes, there are few structural remains or historic debris (which are not recent) in this general area, and few traces of the early 1860 homesteads. Corncribs are commonly found in this general area and appear to have been constructed and utilized at least through the 1930s (Kelly and Roemer 1981). The presence of corncribs at a historic site was therefore not considered to be of sufficient importance to warrant further archaeological investigation. 
The archaeologists were able to obtain valuable information from local informants about some of the identified historic sites. This information was gained through chance meetings with these individuals, however. Information regarding complete property ownership transactions within the project area is provided by Cox's deed record research (see appendix). It is suggested for future archaeological and historical investigations of this area, that time be allotted specifically for locating and interviewing local occupants of the area to be investigated, and also historical records research, including courthouse records, prior to surveying the area so that this information can be better utilized. Recent studies of historical sites (see Jackson 1985) have included analysis of tree-ring specimens, which may provide for more precise dating of historical structures. This technique might be useful for sites which cannot be otherwise dated due to inadequate documentation or artifactual remains.

\section{REFERENCES CITED}

Arbingast, S. A., L. G. Hennamer, R. H. Ryan, A. Lo, D. L. Karney, C. P. Zlatovich, M. E. Bonine, and R. G. Steele

1973 Atlas of Texas. Bureau of Business Research, The University of Texas at Austin.

Black, S. L. and A. J. McGraw

1985 The Panther Springs Creek Site: Cultural Change and Continuity in the Upper Salado Creek Watershed, South-Central Texas. Center for Archaeological Research. The University of Texas at San Antonio, Archaeological Survey Report 100.

Brown, K. M.

1986 Archaeological Studies at the CPS Butler Lignite Prospect, Bastrop and Lee Counties, Texas, 1983. Center for Archaeological Research, The University of Texas at San Antonio, Archaeological Survey Report 140.

Brune, $G$.

1981 Springs of Texas. Volume 1 of two volumes. Branch-Smith, Inc., Fort Worth, Texas.

Bryant, V. M., Jr. and H. J. Shafer

1977 The Late Quaternary Paleoenvironment of Texas: A Model for the Archeologist. Bulletin of the Texas Archeological Society $48: 1-25$. 
Bureau of Economic Geology

1974 Geologic Atlas of Texas. Austin Sheet. The University of Texas at Austin.

Campbe11, T. N.

1983 Espinosa, 01 ivares and the Colorado River, Indians, 1709. La Tierra 10(2):2-12.

Casey, A. (Mrs. J. Casey)

1980 Personal communication with E. Roemer, Jr., July 11, Elgin, Texas. Personal field journal for the CPS-Butler, phase I survey, on file at the Center for Archaeological Research, The University of Texas at San Antonio.

Clark, J. W., Jr.

1968 Archeological Reconnaissance in Bastrop County, Texas. The Bul1 Roarer 3(2):6-9.

Clark, Mr. and Mrs. L. S.

1984 Personal communication with Anna J. Taylor. September 12. Personal field journal for the CPS-Butler, phase IV survey, on file at the Center for Archaeological Research, The University of Texas at San Antonio.

Duke, P. L.

1977 Lake Thunderbird Site (41 BP 78), Bastrop, Texas. La Tierra $4(3): 15-26$.

Eaton, J. D.

1983 Correspondence with M. F. Clausewitz, concerning the CPSButler, phase IV survey. On file at the Center for Archaeological Research, The University of Texas at San Antonio.

Elgin Historical Committee

1972 Elgin. A History of Elgin, Texas, 1872-1972.

Fox, D. E.

1983 Traces of Texas History: Archeological Evidence of the Past 450 Years. Corona Publishing Company, San Antonio.

Gilmore, K. K.

1969 The San Xavier Missions: A Study in Historical Site Identification. State Building Commission, Archeological Program, Report 16. Austin. 
Gould, F. W.

1975 Texas Plants. A Checklist and Ecological Summary. Texas Agricultural Experiment Station, Texas A\&M University, College Station. Revised edition.

Hal1, G. D.

1983 Personal correspondence with L. Herrington, concerning the CPS Butler, phases II and III survey. On file at the Center for Archaeological Research, The University of Texas at San Antonio.

Hester, T. R.

1981 Project Summary. In Archaeological and Historical Investigations in Bastrop and Lee Counties, Texas, by T. C. Kelly and E. Roemer, Jr., :iv-v. Center for Archaeological Research, The University of Texas at San Antonio, Archaeological Survey Report 101.

Hester, T. R. and R. C. Parker

1970 The Berclair Site: A Late Prehistoric Component in Goliad County, Southern Texas. Bulletin of the Texas Archeological Society $41: 1-12$.

Hobbs, L. C.

1984 Personal communication with Anna J. Taylor. September 6. Personal field journal for the CPS-Butler, phase IV survey, on file at the Center for Archaeological Research, The University of Texas at San Antonio.

Hoerman, V. (Mrs. N. W. Hoerman)

1980 Personal communication with Erwin Roemer, Jr. July 11. Personal field journal for the CPS-Butler, phase I survey, on file at the Center for Archaeological Research, The University of Texas at San Antonio.

Jackson, J. M.

1985 Archeological Investigations at the West-Adkisson Cabin Site, 41 WM 566, Wi11iamson County, Texas. Prewitt and Associates, Inc., Reports of Investigations 46 . Austin.

Jelks, E. B.

1962 The Kyle Site: A Stratified Central Texas Aspect Site in Hill County, Texas. Department of Anthropology, The University of Texas at Austin, Archeology Series 5. 
Jenkins, J. H. III, editor

1958 Recollections of Early Texas. The Memoirs of John Holland Jenkins. University of Texas Press, Austin.

Johnson, E.

1977 Animal Food Resources of Paleoindians. The Museum Journal $17: 65-77$. Lubbock.

Johnson, L., Jr., D. A. Suhm, and C. D. Tunne 11

1962 Salvage Archeology of Canyon Reservoir: The Wunderlich, Footbridge and Oblate Sites. The University of Texas at Austin, Bulletin of the Texas Memorial Museum 5.

Jones, W. K.

1969 Notes on the History and Material Culture of the Tonkawa Indians. Smithsonian Contributions to Anthropology 2(5). Washington, D. C.

Jordan, T. G.

1978 Texas Log Buildings: A Folk Architecture. University of Texas Press, Austin.

Kelley, J. C.

1947a The Cultural Affiliation and Chronological Position of the Clear Fork Focus. American Antiquity 13(2):97-109.

1947b The Lehmann Rock Shelter: A Stratified Site of the Toyah, Uvalde and Round Rock Foci. Bulletin of the Texas Archeological and Paleontological Society 18:115-128.

Kel1y, T. C. and E. Roemer, Jr.

1981 Archaeological and Historical Investigations in Bastrop and Lee Counties, Texas. Center for Archaeological Research, The University of Texas at San Antonio, Archaeological Survey Report 101.

Kenmotsu, R. D.

1982 Cultural Resource Investigations at the Powel1 Bend Prospect, Bastrop County, Texas. Texas Archeological Survey, The University of Texas at Austin, Research Report 84.

Killen, Mrs. J. C., editor

1974 History of Lee County, Texas. Lee County Historical Survey Committee. 
Moore, B.

1973 Bastrop County 1691-1900. Educator Books, San Angelo.

Newcomb, W. W., Jr.

1961 The Indians of Texas. University of Texas Press, Austin.

Nightengale; B. A. and J. M. Jackson

1983 An Intensive Survey of the Cultural Resources of the Cummins Creek Prospect, Fayette County, Texas. Texas Archeological Survey, The University of Texas at Austin, Research Report 86.

Pearce, J. E.

1932 The Present Status of Texas Archeology. Bulletin of the Texas Archeological and Paleontological Society 4:44-54.

Pierce, G. S.

1969 Texas Under Arms. The Encino Press, Austin.

Pool, W. C.

1975 A Historical Atlas of Texas. The Encino Press, Austin.

Prewitt, E. R.

1974 Archeological Investigations at the Loeve-Fox Site, Williamson County, Texas. Texas Archeological Survey, The University of Texas at Austin, Research Report 49.

1976 The Rogers Springs Site: 1974 Investigations. Unpublished manuscript. Texas Archeological Survey, The University of Texas at Austin, Research Report 54.

1981 Cultural Chronology in Central Texas. Bulletin of the Texas Archeological Society 52:65-89.

Prikryl, D. and C. S. Ragsdale

1984 Inventory and Assessment of Cultural Resources, Scofield Farms Development, Travis County, Texas. Prewitt and Associates, Inc., Reports of Investigations 31. Austin, Texas.

Ray, C. N.

1934 Flint Cultures of Ancient Man in Texas. Bulletin of the Texas Archeological and Paleontological Society 6:107-111.

1938 The Clear Fork Culture Complex. Bulletin of the Texas Archeological and Paleontological Society 10:193-207. 
Ray (continued)

1945 Stream Bank Silts of the Abilene Region. Bulletin of the Texas Archeological and Paleontological Society 16:117-147.

Sayles, E. B.

1935 An Archeological Survey of Texas. Gila Pueblo, Medallion Papers 17.

Shafer, H. J.

1971 Late Prehistory of Central Texas. Paper presented at the 27th Annual Meeting of the Texas Academy of Science, Stephen F. Austin State University, Nacogdoches, Texas.

Skelton, D. W. and M. D. Freeman

1979 A Cultural Resource Inventory and Assessment at Camp Swift, Texas. Texas Archeological Survey, The University of Texas at Austin, Research Report 72.

Sjoberg, A. F.

1953 The Culture of the Tonkawa, A Texas Indian Tribe. The Texas Journal of Science 5:280-304.

Sollberger, J. B. and T. R. Hester

1972 The Strohacker Site: A Review of Pre-Archaic Manifestations in Texas. Plains Anthropologist 17(58):326-344.

Sorrow, W. M., H. J. Shafer, and R. E. Ross

1967 Excavations at Stillhouse Hollow Reservoir. The University of Texas at Austin, Papers of the Texas Archeological Salvage Project 11.

Souté, c.

1983 Personal correspondence with J. D. Eaton, concerning the CPSButler, phase IV survey. On file at the Center for Archaeological Research, The University of Texas at San Antonio.

Stephenson, R. L.

1970 Archeological Investigations in the Whitney Reservoir Area, Central Texas. Bulletin of the Texas Archeological Society

Suhm, D. A. $41: 37-286$.

1957 Excavations at the Smith Rockshelter, Travis County, Texas. The Texas Journal of Science $9(1): 26-58$. 
Suhm (continued)

1960 A Review of Central Texas Archeology. Bulletin of the Texas Archeological Society 29:63-107.

Suhm, D. A., A. D. Krieger, and E. B. Jelks

1954 An Introductory Handbook of Texas Archeology. Bulletin of the Texas Archeological Society 25.

Taylor, A. J., A. A. Fox, and I. W. Cox

1986 Archaeological Investigations at Morgan Chape1 Cemetery (41 BP 200), A Historic Cemetery in Bastrop County, Texas. Center for Archaeological Research, The University of Texas at San Antonio, Archaeological Survey Report 146.

Turnipseed, H., Jr.

1984 Personal communication with Anna J. Taylor. September 6. Personal field journal for the CPS-Butler, phase IV survey, on file at the Center for Archaeological Research, The University of Texas at San Antonio.

Webb, W. P., editor-in-chief

1952 The Handbook of Texas. Two volumes. The Texas State Historical Association, Austin.

Weir, F. A.

1976 The Central Texas Archaic. Unpublished Ph.D. dissertation, Washington State University, Pullman.

Young, W. C.

1984 The Wilson-Leonard Site, 41 WM 235: The PaTeo-Indian Components. Paper presented at the 55th Texas Archeological Society Annual Meeting, Midland. 


\section{APPENDIX \\ PROPERTY OWNERSHIP RECORDS FOR THE SURVEY AREA \\ I. Waynne Cox}

\section{INTRODUCTION}

The study area lies within a portion of 1 and that was included within three of the original land districts established by the Republic of Texas in 1836 (Bastrop, Washington, and Milam). The exact limits of these districts were general in nature and are extremely difficult to re-establish from the surviving records. The majority of the survey area was within the limits of the Bastrop and Washington Land Districts (GLO 1975). Due to its proximity to the "Camino Real" or "07d Spanish Road," first established by Domingo Teran de los Rios in 1691, the area was explored throughout the early history of the state (Webb 1952 Vol. II:309). However, the history of this area as reported by Brown (1986) and Taylor (this report) have indicated, settlement in the area was quite late in taking hold. In fact, as late as 1857 only 242,863 acres were under tax assessment (or approximately $8 \%$ ) compared to the more than 2,000,000 acres included within the land districts (Texas Almanac $1857,1965)$. The 1830 record of 1 and grants, compiled from the records of the Government Land Office, indicate that only 35 parcels had been granted, and only 27 more were granted during the next 10 years (White 1983:passim). As late as the period immediately prior to the Civil War there were only seven communities considered populous enough to warrant establishment of a U.S. Postal Office (Texas A1manac 1857). It was not unti1 1874 that Lee County was established as a separate county (Webb 1952 Vol. II:45). Both counties are still primarily agricultural, the people are farmers, stockmen, and small businessmen as has been the case throughout their history (Webb 1952 Vol. I:121, Vol. II:45; Texas Almanac 1965:190, 243).

The survey area (as indicated broadly by the shaded area on Fig. 13) includes a11, or portions of, eight original land grants issued by either the Republ ic or State of Texas between the years of 1838 and 1863 . The tracts, for the most part, remained intact and discernible until the period from the late 1870s to the early 1900s, when they began to be subdivided or merged into other holdings. There is no indication within the deed records as to the construction of any structures. This is a common problem when dealing with rural tracts. Individual constructions can best be evaluated in light of their major architectural styles, although this may be masked by later alterations, and the original feature is often not discernible by mere visual examination. Generally more information can be gained through oral history rather than through written records.

In examining the ownership records of these properties, one does not encounter the dynamic, and often dramatic, changes that are often evident when dealing with the more populous and urban areas. The historic, and frequently notorious, personages so often involved with town lots, public lands, and speculative properties are absent. Instead we are dealing with the slow, steady growth of agricultural land that is so necessary to support and feed the city. Yet these are the portions of the state that provide the stability for the economy and the predictable tax base upon which the state 


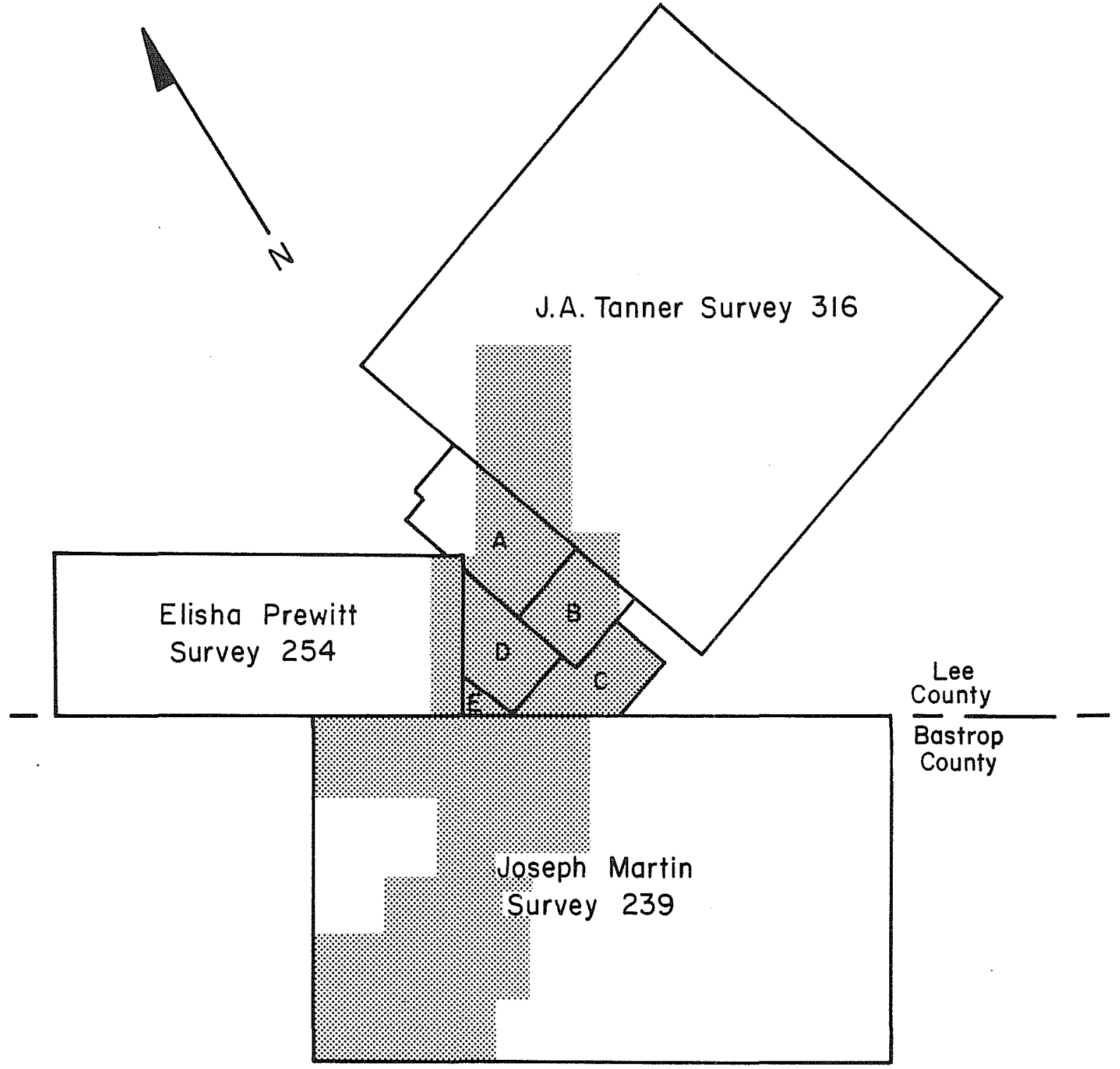

A John G. Willet Survey A-345

B Franklin J. Williams Survey 341

C William B. Mauldin Survey 235

D Abner Bankston Survey 45

E James L. Ferguson Survey 379

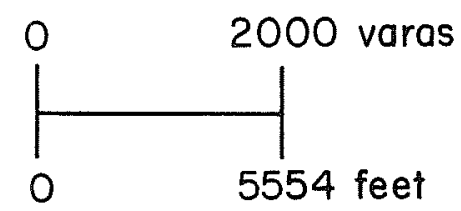

\section{Original Land Grants}

Figure 13. Original Land Grants Issued by the State of Texas Within the Survey Area. Shading represents survey area. 
is anchored. In researching urban properties, the addition of a structure constitutes a major improvement, and reflects its presence with a marked inflation of either the selling price or the tax appraisal. This is not the case with rural properties. The construction of a home, barn, or other structure is considered a necessary development of the property and is not included to the same extent in the overall evaluation of its value. Furthermore, due to the larger acreage involved, the uses of the holdings tend to vary over time, with unequal market values reflected, dependent upon the agricultural value of productive capabilities of the land that are not evident to the researcher relying entirely on metes and bounds limits and leasing or selling price. Yet, tracing the history of property exchanges may still indicate, although in a more subtle manner, the changing factors that effect not only the individual properties but the entire region.

Genera77y, more information can be gained through oral history rather than through written records. In dealing with these land parcels, segments of the land holdings were separated, combined with adjacent tracts, or realigned with other tracts within the survey. Therefore, some of the titles and transfers were omitted in order to clarify the major thread of ownership as it affected and molded the land usage patterns. A complete abstract of title, including these minor divisions and transfers, is on file with the Center for Archaeological Research, UTSA, and the legal office of City Public Service, San Antonio, Texas.

\section{THE HISTORY OF THE PROPERTIES}

Joseph Martin Survey Number 239

A First Class Land Grant was issued by the Republic of Texas to Joseph Martin on February 2, 1838, by virtue of the immigration of Martin and his wife, Frances, in 1832. As provided by the laws of the Republic, each citizen who was present prior to its creation in 1836, was entitled to a league and a labor of public land. A league of 1 and was equivalent to 5000 square varas or 4428.4 acres, a 1abor 1000 square varas or 177.1 acres (GLO 1982). Hence, Martin had a legal claim on 4605.5 acres of public land anywhere in the Republic not previously claimed. This was only "paper acreage" until located, surveyed, and patented by the Republic. The required survey ". . . On the east side of the Colorado River, 18 miles north of Bastrop..." was conducted on April 16, 1838, indicating that the land contained ". . . 10 Tabours of temporal (or arable) 1 and and 16 labours of pasture." The established filing fee for each labor of arable land was $\$ 2.50$, and $\$ 1.20$ for each labor of pasture (GLO n.d., File No. 68). Therefore, Martin applied for and acquired a patent on the 1 and in March 1841 , at a total cost of $\$ 44.20$, for which he paid the required $10 \%$ down.

Prior to actually taking physical possession of the property, Joseph Martin died intestate, and the property was conveyed by the Republic to Leander C. Cunningham in January 1842 (GLO n.d., File No. 68; BCDR Vol. C:455). Cunningham probably began ranching on the land shortly after that time, because the census of 1850 indicated he owned ". . . three horses, twenty asses of mules, two working oxen, thirty other cattle, and twelve swine." There are no crops listed, with the exception of 18 bushels of potatoes, but 
he did produce 250 pounds of butter and slaughtered $\$ 50$ worth of animals (Texas Agricultural Census 1850). By 1860, he had improved 36 of his acres, increased his cattle to 62, and his swine to 100 . He also produced 100 bushels of corn, 100 pounds of butter, and slaughtered $\$ 100$ worth of livestock (Texas Agricultural Census 1860). That same year, Martin's heir and only daughter, Lucinda M. Hammond, sued Cunningham on behalf of herself and her mother, Mrs. William H. Wheat, for a portion of the estate. In an agreement concluded in August 1860, they were awarded the northwest and southeast one-thirds of the property (BCDR Vol. L:666).

In 1868, Cunningham sold 1035 acres of his remaining portion of the grant to Harris J. Howard for $\$ 1500$, and two years later sold A. M. Brooks 500 acres for $\$ 1.00$ an acre (BCDR Vo1. 0:492, Vol. P:455). A. M. Brooks conveyed his portion to Charles W. Brooks the same month, and then Charles Brooks purchased the Howard 1 and that same year, reuniting the tract (BCDR Vol. $P: 455-456)$. In the census of that year, C. W. Brooks had 172 head of livestock, 30 swine, and produced 200 bushels of corn and two bales of cotton (Texas Agricultural Census 1870).

In August 1869, the remaining Cunningham land was acquired by the sheriff, as a result of a damage suit brought against Cunningham by Joseph M. Cowe11, Joseph Fanera, and Edward C. Miller, and placed into the hands of the firm of Jones and Sayers (BCDR V01. 0:636). The firm also purchased the Howard tract from J. M. Middlebrook and his wife, Harriett (Howard), in October 1869, excluding four acres donated for a church and school (Shiloh School; BCDR Vol. P:46). In December 1872, George W. Jones and Joseph Sayers sold the 7 and to James L. Cunningham (BCDR Vol. U:712). He, in turn, sold the tract to J. C. Higgins, who sold a portion to C. B. Garwood in 1875 (BCDR Vol. U:710). Higgins and Garwood later sold their combined interest to W. F. Cruse in January 1886 (BCDR Vol. 8:222). W. F. Cruse and his wife, A. M., conveyed the property to Josh Browning on November 28, 1899 (BCDR Vol. $33: 191)$.

A portion of the Brooks tract was transferred by $C$. W. Brooks to A. W. McLean in March 1883 (BCDR Vol. 15:577). McLean sold the property to J. F. Wilson in 1892 (BCDR V01. 22:35). Wilson and his wife, M. J., conveyed the acreage to Josh Browning in April 1925, thus rejoining the property (BCDR Vol. $79: 31)$. Browning retained the tract until December 1948 , when he sold it to Martin Kastner (CPS Abstract File:Martin). The Brooks tract was conveyed to the city of San Antonio in 1983 (BCDR Vol. 423:594).

The division of the property awarded to W. H. and Francis Wheat and William B. and Lucinda Hammond was conveyed to John C. White in April 1863 (BCDR Vol. $0: 255)$. He sold the property to Hugh L. Harkins in 1868 (BCDR V07. P:255). The tract then passed, with numerous subdivisions, through the hands of the Harkins heirs until it was conveyed to H. W. Wolf between 1899 and 1900 (BCDR Vol. 15:540, Vol. 17:151, Vol. 26:477, Vol. 30:251, 253, Vol. 33:268). It then passed to the Wolf heirs upon his death in 1950 (BCDR Vol. 103:33; BCPCR No. 2957).

Two smaller tracts, 176 and 134 acres, were subdivided from the Harkins purchase of 1868 and the White purchase of 1863 and were separately sold in the early 1870s. In 1871, White sold an interest in the larger division to 
Obed Nu11, and they jointly mortgaged the tract to J. C. Higgins and J.W. Holman (BCDR Vol. Q:168, Vol. R:141). They conveyed the property to T. F. Crosby in 1875, who in turn sold the title to A. B. Townsend the following year (BCDR Vol. W:367, Vol. V:109). Townsend, and his wife, then sold the tract to Mrs. Lydia C. Hackworth (BCDR Vo1. V:263). The Haskin tract, 134 acres, was mortgaged to Alfred Shepard in 1872. He sold it to George Bigby in 1894 (BCDR Vol. R:133, Vol. 22:323). Bigby, joined by this wife Kate, conveyed the property to M. A. Hackworth in 1908, who had acquired the previous tract from Lydia Hackworth (BCDR Vo1. 44:367). Hackworth leased the oil rights to the Texas Company (Texaco) in 1924, and the Hackworth family sold the property to J. G. Puterbaugh in 1952 (BCROL; BCDR Vo1. 135:184).

\section{J. A. Tanner Survey Number 316}

A tract was granted under the headright of $\mathrm{J}$. A. Tanner as an entitlement to the standard one league and a Tabor under the laws of the Republic. Tanner and others were the first settlers of the area known as the "Yegua Knobbs" (Killen 1974). As is often the case with headright grants, it was transferred by Tanner to $E$. W. Cullen as his assignee. This was a common practice in the speculative early years of the Republic with its generous land policies--the consideration given for the transfer is seldom noted. Cullen and his wife arrived in the Republic in autumn 1835, making him eligible for a similar grant of land. The fact that he secured this entitlement probably indicated that he was involved to some degree in the speculative land game that was so prevalent during the period. The 1and was surveyed in February 1838, and attested as having two 1abors of arable 1 and and 24 of pasture. The final patent was approved September 26, 1845 (GLO n.d., No. 1-207; LCDR Vol. A:24). The following year, Cullen conveyed title to M. Cartwright (LCDR V01. A:25). In 1855, the property was seized by Sheriff Robert W. Scott for nonpayment of taxes. The 1 and was then purchased at public auction by Daniel D. Atchison (LCDR Vol. B:405). Atchison sold the property to Charles Buckholt in March of the following year (LCDR Vol. C:186). He, in turn, conveyed the tract to John A. Buckholt in 1859 for $\$ 4000$, less than a dollar an acre (LCDR Vol. C:189). John Buckholt sold the 1and to F. S. Wade in 1867 (LCDR Vol. F:166).

In May 1871, the heirs of M. Cartwright, Amanda, Linda, and Arthur Cartwright, joined with Anna W. Robert, and her husband, B. J., to sue for the property. Amanda, the widow of Matthew, stated that at the time the property was seized, Matthew was a minor (LCDR Vol. E:449). They, in turn, sold the tract to Mary C. Ingram (LCDR Vol. F:146). The property later passed to J. M. Ingram. Ingram sold off several subdivisions of the 1 and over the next 36 years. He sold one tract to George and Lillie King in 1886, who conveyed it to H. R. Thames in 1889 (LCDR Vol. L:408, Vol. 48:225). The heirs of Roxie Thames, Paul, Henry Erby, and Earl Herman Lewis, sold a portion of the property to W. R. Gillum in October 1928 (LCDR Vol. 48:401). other heirs, C. B. and Courtney (Birdie) Craig, Elmer Stewart (surviving husband of Lela Thames), Zada and Oscar Taylor, Elsie and Henry Brinkey, and Dee and Gertrude Craig, sold the remaining portion to Gillum in November (LCDR Vol. 48:327, Vol. N:501). Due to various legal claims against the estate, Gillum did not obtain clear title to the land until 1946 (LCDR Vol. $67: 266$, Vol. 68:56, Vol. 93:364, 365). The following year, Gi11um sold the 
tract to W. M. Smith (LCDR V01. 96:596). Smith conveyed the property to Charles and Lovella Ryan in 1950, who sold it to B. J. Antle in 1955 (LCDR V01. 96:596, V01. 105:385, Vol. 119:618). B. J. and Verna Antle sold the property to the Texas Veterans Land Board in 1971, who conveyed it to Bi11 S. Thompson, who sold it to Edward Neal in 1974 (LCDR Vol. 196:19, 22, Vol. 226:343). Neal, with his wife Florence Marie, sold the land to the city of San Antonio in 1984 (LCDR Vol. 463:683).

J. M. Ingram sold another portion of the property to P. A. Guthrie in January 1890 (LCDR Vol. P:498). The 1and was retained by the Guthrie family unti1 the heirs conveyed the titles in various subdivisions to C. H. Edwards, A. J. Clopton, and others during the period from 1932 through 1936 (LCDR Vol. $63: 366$, Vol. 64:5, Vol. 68:372). The land finally passed through C. H. Eddleman and Pearl M. 01iver to the Veterans Land Board (LCDR Vol. 75:14, Vol. 79:363, Vol. 105:207, Vo1. 112:198, Vo1. 114:365). The Veterans Land Board conveyed the property to Everett Harding in 1962, who sold it to the city of San Antonio in 1983 (LCDR Vol. 142:430, Vol. 437:298, Vol. 439:80).

S. W. Ingram sold a final division to J. S. Walker in 1912 (LCDR Vol. $23: 237)$. This property passed to S. H. Mundine in 1913, and through his various heirs, the Jacksons, Fishers, and Craigs to L. F. Clark, Jr., in the period from 1963 to 1966 (LCDR Vol. 37:472, Vol. 76:576, Vol. 119:238, Vol. 150:170, Vol. 152:170, 242, Vol. 155:147, Vol. 426:636). Clark and his wife, LaVerne, sold their interest to the city of San Antonio in May 1983 (LCDR V01. 426:643).

\section{Elisha Prewitt Survey Number 254}

Elisha Prewitt, who emigrated to Texas in 1820, was granted title to onethird of a league of 1 and (1476 acres) by Governor Albert C. Horton. It was surveyed in January 1838, the taxes paid by Prewitt in 1841, and final patent was granted in August 1846 (GLO n.d., No. 432). The 1 and Tater passed to James and Nancy Floyd in August 1859 (LCDR Vol. D:168). The following year, Floyd sold a portion to John R. George (LCDR Vo1. D:172). They occupied the remainder as their homestead until 1875, then sold the property in two parcels to Marion Hughes and Eugene Bremond (LCDR VoT. A:99, 381). At the time of the sale, James and Mary Floyd were residing in McDade, and their son, W. B. and his wife Mary, were living on the Prewitt tract (LCDR Vol. $A: 99)$. Marion Hughes then conveyed 200 acres back to W. B. and Mary for $\$ 900$ (LCDR Vol. A:414). Eugene Bremond sold his portion (743 acres) to Joseph W. Hanning in May 1876 (LCDR Vol. B:294). These transactions were probably a result of interfamily settlements since Bremond acted as a trustee during the transfers. Hanning sold his portion to John H. and Mary Ziviey in October 1876 (LCDR Vol. B:294). The 1880 agricultural census shows that Zivley was actively working the tract in that year (Texas Agricultural Census 1880). At that time a court suit was brought against the property, resulting in a major division of the plat between Zivley, Hanning, Floyd, R. S. Willis, N. B. Scott, S. C. Garrett, and M. J. Elkins (plat on file, LCDR Vol. 11:323, Vol. $E: 165$, Vo1. F:387, Vol. A:429; LCDCR No. 266). At this time, several redistributions of the 7 and caused it to merge with portions of the Bankston and Mauldin grants, obliterating much of the Prewitt land as a separate tit7e, but much of the property became a portion of the Scott and Floyd 
divisions passing to the Browning family and is further traced under the Martin survey.

\section{William B. Mauldin Survey Number 235}

William Mauldin filed a preemption claim for 160 acres of public 1 and which he stated that he had occupied and improved prior to filing the claim. The 1 and was surveyed in 0ctober 1856, and patent was granted in March 1860 (GLO n.d., No. 3-1850). William B. and his wife, Elizabeth E., sold the property in March 1860 to William and L. J. Mills (LCDR Vol. C:313). The Mills heirs, W. A. and S. C. Mi11s, Mrs. Z. Jones, Martha McCreghton, Mrs. Lynda Branton, J. V., J.W., W. J., and A. D. Fisher, and Mrs. A. J. Williams, sold the tract to T. W. Owens in 1919 (LCDR Vol. 31:187). He sold the property to Rueben and Fannie Massey in 1920, who, in turn, conveyed it to M. C. Parrish in 1922 (LCDR Vol. 33:383, Vol. 37:589). A court suit, Mills, et al. vs. Massey, et a1. resulted in clear title being awarded to Parrish in 1931 (LCDCR Apri1 Term 1929; LCDR V01. 57:318). Parrish sold the land the same year to A. C. Bull (LCDR Vol. 59:317). Bul1, in turn, conveyed the land to Pleasant A. and Amelia Helms, but the title was not properly filed, so that in 1961, Helms was required to confirm by affidavit that he had owned and occupied the 1and since 1936 (LCDR Vol. 137:69). Helms sold the property to James D. and Margie Irene Webb in October 1961 (LCDR Vol. 133:502). They conveyed the property to the city of San Antonio in 1983 (LCDR Vol. 169:390).

\section{Frankl in J. Williams Survey Number 341}

The state granted F. J. Williams 160 acres of public land the first of April 1859, on the basis of a preemption claim that he had resided upon and cultivated the tract since the first day of August 1856. This was attested to by James Floyd, his neighbor, on the Prewitt survey (GLO n.d., No. B-389). Williams sold the property to Presley E. George on November 30, 1865 (LCDR Vol. F:412). George sold the tract to A. W. Parr in 1867 (LCDR Vol. E:472). He conveyed the property to A. A. Parr in March 1899 (LCDR Vol. 15:343). A. A. Parr sold the property to P. H. Wilson in 1912 (LCDR Vol. $24: 349)$. P. H. Wilson died in 1950, at which point his widow, Annie, and their children, Joe Willie and Elsie Bessie, conveyed the property to the Veterans Land Board (LCDR Vo1. 103:243, 457).

\section{Abner Bankston Survey Number 45}

Abner Bankston was granted 160 acres of 1 and on a preemptory claim that ". . . on the 12th day of February, 1855, he settle upon a portion of the pubiic domain." The claim was filed, and a survey conducted in May 1858, with final patent approved and awarded on February 19, 1859 (GLO n.d., No. B3-17). In October 1859, Bankston and his wife, Susan, conveyed the property, including the "Yegua Creek Mine," to David Scott for $\$ 600$ (LCDR Vol. C:309). In 1862, David and Elizabeth Scott sold the tract to Hugh L. Harkins for $\$ 800$ (LCDR Vol. C:311). William H. Harkins and wife, Emma, later sold the 160 acres to W. J. Hackworth in 1897 (LCDR Vol. B:553). Through various deeds within the Hackworth family, the property passed to M. Allie Hackworth, who sold it to W. E. Lawhon in March 1916 (LCDR Vo1. 42:241). Lawhon was the 
husband of Rhoda (Hackworth), the eldest child of Allie, and in 1923, the property was inherited by Rhoda, Vivian Lawhon, Bessie Sherman, John and Ervin Lawhon, and Mrs. Wi17ie Browning (LCDR Vo1. L:531). The property was combined through the Browning 7 ine with the property covered under the Martin survey section.

\section{James L. Ferguson Survey Number 379}

James Ferguson was granted a 40 -acre tract on a preemption claim that he had settled upon ". . . vacant public domain," and a survey was conducted in July 1860, and final patent was approved in February 1863 (GL0 n.d., No. M-5-593). Ferguson and his wife sold the property to $S$. C. Garrett at the time for $\$ 300$ (LCDR V01. D:175). A short time later this tract was combined with portions of the Bankston survey, and in the subdivision of the 1880 s passed to the Lawhon interest as explained in the coverage of the Prewitt survey (LCDR Vol. $42: 24)$. It is further discussed with the Lawhon heirs property in the Bankston survey (LCDR Vo1. L:531, Vol. 73:204).

\section{John G. Willet Survey Number A-345}

John Willet claimed 320 acres under a preemptory claim that he had ". . resided upon and cultivated..." the tract for three consecutive years, placing him on the property in 1851. He had the land surveyed in 1854 and received his patent in May 1857 (GLO n.d., No. 3-1419; LCDR Vol. $251: 383)$. He passed one-half of the property to Nathan A. Willet in 1857 for $\$ 100$, and both portions were acquired by Thomas Bowles, who sold the 1 and to Thomas J. Walker in December 1869 for $\$ 2000$ (LCDR Vol. 16:155). Walker divided the 1 and in 1903, and conveyed the western half to J. S. Walker and the eastern half to A. S. Oglesby (LCDR Vol. 14:300, Vol. 16:155). J. S. Walker died in 1937, and his wife, Demarious, followed him the next year (LCDR Vo1. 141:575). The heirs, J. G., Mary W., Eva W., MiTarda W., and Willis Walker, sold their portion to Calvin C. and 01 ive W. Huffman in October 1963 (LCDR Vol. 151:271). Calvin Huffman died in 1980 at age 72, and his wife and heirs acquired the property, now incorporated. They conveyed the property to Norman Bunnett in Apri1 1983 (LCDR V07. 425:558). Bunnett, and others, sold it to the city of San Antonio in 1983 (LCDR Vol. 425:558, Vol. $437: 905,910)$.

The Oglesby portion, along with other lands of the Tanner league, sold to William Bostic in 1906 (LCDR V01. 16:365). It was conveyed to the Ingram interest as reported with the Tanner survey.

\section{RESULTS OF DEED RECORD SEARCH BY TRACT}

\section{Tract 4}

Site 41 BP 272

The ruins of a structure on tract 4 are located on the 1 and acquired by M. A. Hackworth in 1908 (see Joseph Martin Survey Number 239), but were probab7y 
constructed prior to their occupation. Due to the nature of the artifacts collected (Table 6), they probably date to the period when the land was owned by the Townsends, 1876 to 1908 .

\section{Tract 6}

Site 41 BP 202

A structure on tract 6 was occupied by the Hackworth family in 1910, and obviously had its initial construction prior to their purchase of the land. Due to the estimate that the house was constructed ca. 1880-1900, the probable owner was A. B. Townsend, 1876 to 1880 (see Joseph Martin Survey Number 239). There is no record of an Allison family having owned the property, therefore, the name traditionally attached to this homestead probably occurred when the tract, or some portion of it, was leased or rented.

\section{Tract 7}

\section{Site 41 BP 275}

A standing L-shaped, wooden frame on tract 7 appears to date to the period of the late 1800s to early 1900s. This would place its construction during the period of ownership when the property was in the hands of the Hawkins heirs, 1872 to 1900 , or after the subdivision, to H. W. Wolf, in 1900 (see Joseph Martin Survey Number 239). It is most likely that the structure was constructed by Wolf, since during the period that the property was in the hands of the Hawkins heirs, the emphasis appears to be more toward subdivision and redistribution rather than occupancy.

\section{Tract 10}

\section{Site $41 \mathrm{LE} 88$}

The structure on site 41 LE 88 was probably begun under the period of ownership of A. A. Parr, between 1899 and 1912. The later additions can be attributed to Parks H. Wilson, who acquired the tract in 1912, and occupied the site until his death in 1949 (LCDR Vol. 103:243).

\section{TRACT 13}

\section{Site 41 BP 276}

A portion of the Martin survey in tract 13 was initially conveyed as a 100 acre parcel by his heirs and passed through a series of owners, without any escalation of sale price, until after being acquired by W. B. Taylor in 1883 . Upon selling 28-9/10 acres in 1909, to Oscar and Tena Rother, the price had increased to $\$ 918.75$. This increase probably reflected an improvement to the property by the addition of the structure. 
Tract 15

Site 41 BP 277

The structures and associated features observed on site 41 BP 277 most probably date to the subdivision of tract 15 by the Hackworth heirs after 1945 (BCDR Vol. 115:331).

\section{Tract 16}

Site 41 BP 278

The structure observed on site 41 BP 278 was undoubtedly constructed after the tract was acquired by Ford and Stella Taylor in late 1918 (BCDR Vol. 65:500). The debris scatter observed is most probably associated with the Mt. Pleasant School, since no clear occupation is indicated prior to that time.

\section{Tract 20}

Sites 41 LE 85 and 41 LE 86

The Mundine family acquired the property where sites 41 LE 85 and 41 LE 86 were identified in a division of the heirs of T. C. Cooper, who purchased the property in 1873 and died in 1931 (LCDR Vol. 90:227). Therefore, the ca. 1912 home was probably a second homestead for Cooper. No record of an owner named Voydts was found in the ownership chain.

\section{Tract 23}

\section{Site 41 BP 274}

The corncribs recorded at site 41 BP 274 were probably constructed sometime during the ownership of William Mil1s, who acquired the tract in 1860 (BCDR Vol. C:313). The Mills heirs sold the tract, in 1919, to T. W. Owens. However, corncribs of this type are known to have been constructed until the mid-1930s.

\section{Tract 27}

\section{Site 41 LE 87}

The property where site 41 LE 87 was identified was acquired in 1869 by Thomas J. Walker and was retained by him until his death in 1937 (see James L. Ferguson Survey Number 379). Due to his lengthy occupation, it is most probable that the early foundation, later structure, and the corncrib were constructed during his tenure. 


\section{Tract 30}

\section{Site 41 LE 89}

The deed records do not seem to reflect any early occupation of tract 30 until the property was acquired in 1919 by T. W. Owens (see William B. Mauld in Survey Number 235). Therefore, the homestead and cistern would appear to date from the occupation of Owens or even to M. C. Parrish after 1922.

\section{CONCLUSIONS}

The property ownership records for the tracts within the survey area reveal a pattern that is typical of the majority of the land within the two-county area. They depict a typical agrarian-based central Texas land-use complex. Population density within the area has never been, and is not now, very high. The combined population for both Lee and Bastrop Counties is only 41,900 , or 27 persons per square mile (Texas Almanac 1986). The only major incursion into the mixed farming/stock-raising income has been the exploitation of oil and mineral rights during the 20th century.

The three large tracts of acreage, as might be expected, remained identifiable through time, while the smaller adjacent plats were generally acquired and absorbed rather early. While the history of the development of a typical rural section of central Texas has the potential of contributing to an overa11 understanding of the growth of the state, it must be based upon a broader segment of the region. Nothing in the records indicates the probability of historic structures on any of the properties, other than those already identified, and none of the individuals encountered is historically significant to major events in the state. In future projects of this nature, a consideration of planning for the collection of oral histories should be anticipated. No further research is recommended for this project.

\section{REFERENCES CITED}

Bastrop County, Texas

Bastrop County Deed Records (BCDR)

Bastrop County Courthouse, Bastrop, Texas.

Bastrop County Probate Court Records (BCPCR)

Bastrop County Courthouse, Bastrop, Texas.

Bastrop County Record of $0 i 1$ Leases (BCROL)

Bastrop County Courthouse, Bastrop, Texas.

City Public Service

Abstract Files, legal office, San Antonio, Texas. 
General Land Office (GLO)

1975 Original Land Districts in Texas, map 3-3-75 CLS, developed for Bob Armstrong, Commissioner, Austin Building, Austin.

1982 General Land Office, Texas Land Measure, GLO-SD-(1-82) developed for Garry Mauro, Commissioner, Austin Building, Austin.

n.d. Land Grant Files. Numbers cited in text.

Killen, Mrs. J. C., editor

1974 History of Lee County, Texas. Lee County Historical Survey Committee.

Lee County, Texas

Lee County Deed Records (LCDR)

Lee County Courthouse, Giddings, Texas.

Lee County District Court Records (LCDCR)

Lee County Courthouse, Giddings, Texas.

Texas Agricultural Census

18507 7th Census of Texas, Agricultural Production, Bastrop County. Microfilm. Texas State Library, Austin.

1860 8th Census of Texas, Agricultural Production, Bastrop County. Microfilm. Texas State Library, Austin.

1870 9th Census of Texas, Agricultural Production, Bastrop County. Microfilm. Texas State Library, Austin.

1880 10th Census of Texas, Agricultural Production, Lee County. Microfilm. Texas State Library, Austin.

\section{Texas Almanac}

1857 The Texas Almanac for 1857. Richardson and Company, Galveston.

1965 Texas A1manac, 1964-1965, The Encyclopedia of Texas. A. H. Be7o Corp., Da71as.

1986 Texas Almanac and State Industrial Guide, 1986-1987. A. H. Be10 Corp., Da11as. 
Webb, W. P., editor

1952 The Handbook of Texas. 2 volumes. The Texas State Historical Association, Austin.

White, G.

19831830 Citizens of Texas. Eakin Press, Austin. 